\title{
CHEMICAL ANALYSES OF GROUND-WATER SAMPLES FROM THE RIO GRANDE VALLEY IN THE VICINITY OF ALBUQUERQUE, NEW MEXICO, OCTOBER 1993 THROUGH JANUARY 1994
}

By D. W. Wilkins, Jamie L. Schlottmann, and Dale M. Ferree

\section{U.S. GEOLOGICAL SURVEY}

Open-File Report 95-773

Prepared in cooperation with the CITY OF ALBUQUERQUE PUBLIC WORKS DEPARTMENT

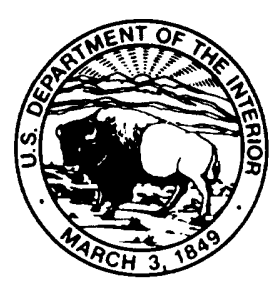

Albuquerque, New Mexico 1996 


\section{U.S. DEPARTMENT OF THE INTERIOR \\ BRUCE BABBITT, Secretary \\ U.S. GEOLOGICAL SURVEY \\ Gordon P. Eaton, Director}

For additional information write to:

\section{District Chief}

U.S. Geological Survey Water Resources Division 4501 Indian School Road NE, Suite 200 Albuquerque, New Mexico 87110-3929
Copies of this report can be purchased from:

U.S. Geological Survey Earth Science Information Center Open-File Reports Section Box 25286, MS 517 Denver Federal Center Denver, Colorado 80225 


\section{CONTENTS}

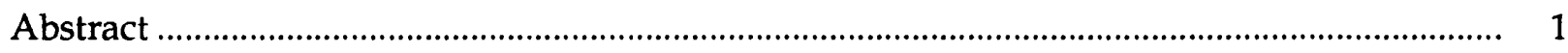

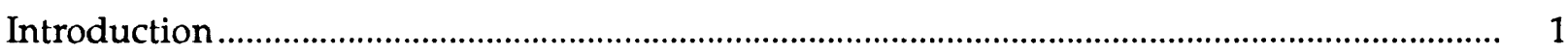

Purpose and scope …….................................................................................................. 2

Well-numbering system ......................................................................................................... $\quad 4$

Description of the study area and wells ............................................................................ 5

Data-collection methods ........................................................................................................... $\quad 7$

Sample-collection methods............................................................................................... $\quad 7$

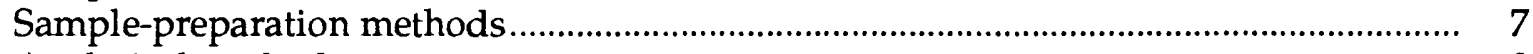

Analytical methods ............................................................................................................ 8

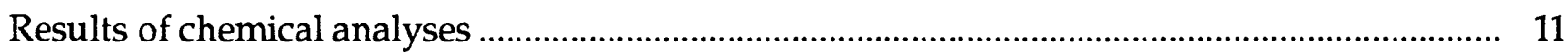

Major ions................................................................................................................... 11

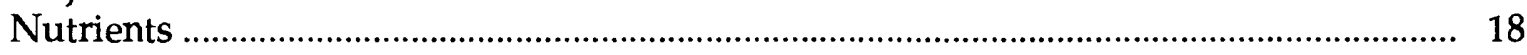

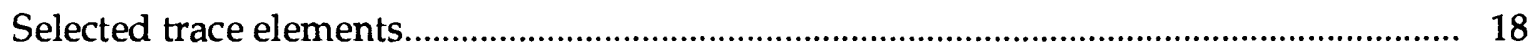

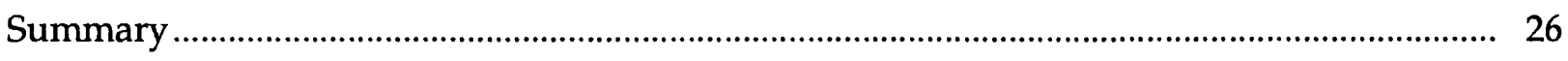

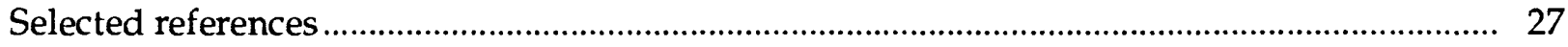

\section{FIGURES}

1. Map showing location of study area and well nests .......................................................... 3

2. Diagram showing well-numbering system for New Mexico.............................................. 4

3-5. Water-quality diagrams showing distribution of dissolved major-ion concentrations in:

3. Shallow wells

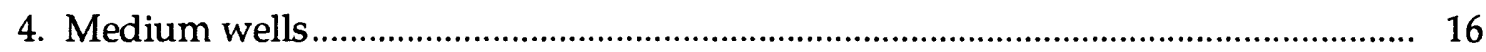

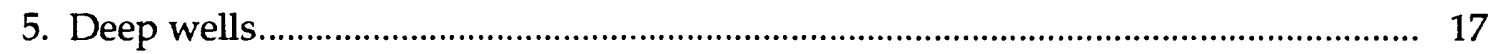

6-8. Bar graphs showing dissolved-nutrient concentrations in water from wells in the:

6. Paseo del Norte section ................................................................................................ 19

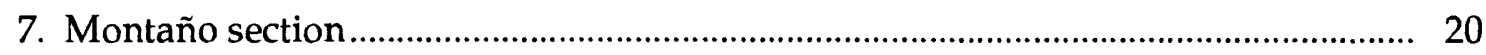

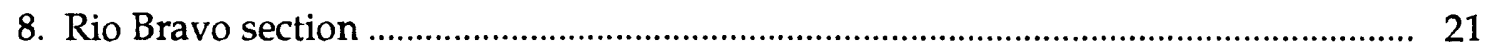

9-11. Bar graphs showing dissolved trace-element concentrations in water from wells in the:

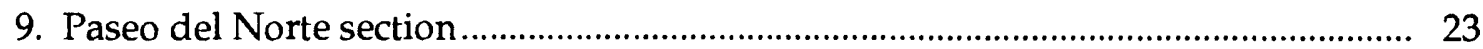

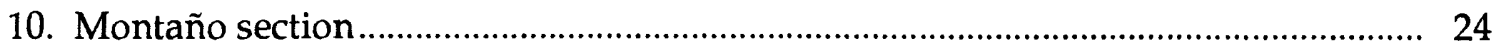

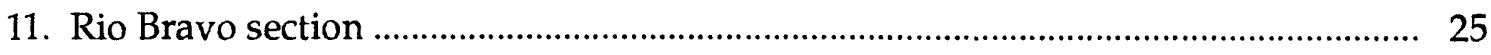




\section{TABLES}

1. Description of sampled observation wells

2. Field procedures for preparation and preservation of water samples for laboratory analysis 8

3. Analytical methods used for total organic carbon and inorganic determinations .............

4. Volatile organic compounds for which water samples were analyzed .............................. 10

5. Physical properties and concentrations of major ions, nutrients, trace elements, and toluene in water samples from observation wells in the Rio Grande Valley in the vicinity of Albuquerque, New Mexico

\section{CONVERSION FACTORS AND VERTICAL DATUM}

Multiply

foot

mile

gallon
By

0.3048

1.609

3.785
To obtain

meter kilometer liter

Temperature in degrees Celsius $\left({ }^{\circ} \mathrm{C}\right)$ can be converted to degrees Fahrenheit $\left({ }^{\circ} \mathrm{F}\right)$ by the equation:

$$
{ }^{\circ} \mathrm{F}=9 / 5\left({ }^{\circ} \mathrm{C}\right)+32^{\circ}
$$

Sea level: In this report sea level refers to the National Geodetic Vertical Datum of 1929--a geodetic datum derived from a general adjustment of the first-order level nets of the United States and Canada, formerly called Sea Level Datum of 1929. 


\title{
CHEMICAL ANALYSES OF GROUND-WATER SAMPLES \\ FROM THE RIO GRANDE VALLEY IN THE VICINITY OF ALBUQUERQUE, NEW MEXICO, OCTOBER 1993 THROUGH JANUARY 1994 \\ By D.W. Wilkins, Jamie L. Schlottmann, and Dale M. Ferree
}

\begin{abstract}
A study was conducted to investigate general ground-water-quality conditions and contaminant locations in the Rio Grande Valley in the vicinity of Albuquerque, New Mexico. Water samples from 36 observation wells in 12 well nests were analyzed. The well nests are located along three roads near the Rio Grande--two well nests near Paseo del Norte, five well nests near Montaño Road, and five well nests near Rio Bravo Boulevard.

The water samples were collected from October 19, 1993, through January 18, 1994. Waterquality types by major-ion composition were calcium bicarbonate (found in most samples), sodium sulfate, calcium sulfate, and calcium sulfate chloride. Nutrients were detected in all but one sample. Ammonia was detected in 34 samples, nitrite in 4 samples, and nitrate in 17 samples. Orthophosphate was detected in 31 samples. Organic carbon was detected in all samples collected. The trace elements arsenic and barium were detected in all samples and zinc in 31 samples. Fourteen samples contained detectable copper. Cadmium was detected in one sample, chromium in two samples, lead in four samples, and selenium in two samples. Mercury and silver were not detected.
\end{abstract}

\section{INTRODUCTION}

Ground-water contamination in the Rio Grande Valley near Albuquerque has been reported by previous investigations (Hines, 1981; McQuillan, 1982). Determining the location of areas containing contaminated ground water will assist local water managers in locating future water-supply wells. 
To investigate general ground-water-quality conditions and contaminant locations in the Rio Grande Valley in the vicinity of Albuquerque, the U.S. Geological Survey, in cooperation with the City of Albuquerque, sampled 36 observation wells in 12 well nests located along three east-west sections (fig. 1). Montaño Road well nests 1-4 and Rio Bravo Boulevard well nests 1-4 were installed in cooperation with the New Mexico Environmental Improvement Division (now the New Mexico Environment Department) and the City of Albuquerque Public Works Department (Anderholm and Bullard, 1987). Paseo del Norte well nest 1, Montaño Road well nest 5, and Rio Bravo Boulevard well nest 5 were installed in cooperation with the City of Albuquerque as part of a project to determine a water budget for the Rio Grande between the levees. Paseo del Norte well nest 2 was installed in cooperation with the City of Albuquerque and the Bureau of Reclamation as part of the water budget study and also for obtaining data for a continuing definition of sediments that compose the local aquifer system. Data obtained from these wells have provided information about water resources of the valley, including groundwater quality as reported in this report. This report was prepared in cooperation with the City of Albuquerque Public Works Department.

\section{Purpose and Scope}

This report presents chemical analyses of ground-water samples collected from 36 observation wells in a reach of the Rio Grande Valley in the vicinity of Albuquerque from October 19, 1993, through January 18, 1994. Descriptions of well completions, sample preservation methods, analytical methods, and results of water-quality analyses are included in several tables in this report. Illustrations are included that display spatial variations of major-ion concentrations at shallow ( 22 to 50 feet), medium ( 75 to 150 feet), and deep (131 to 600 feet) depths, and depict variations in nutrient and trace-element concentrations with depth along three east-west sections. 


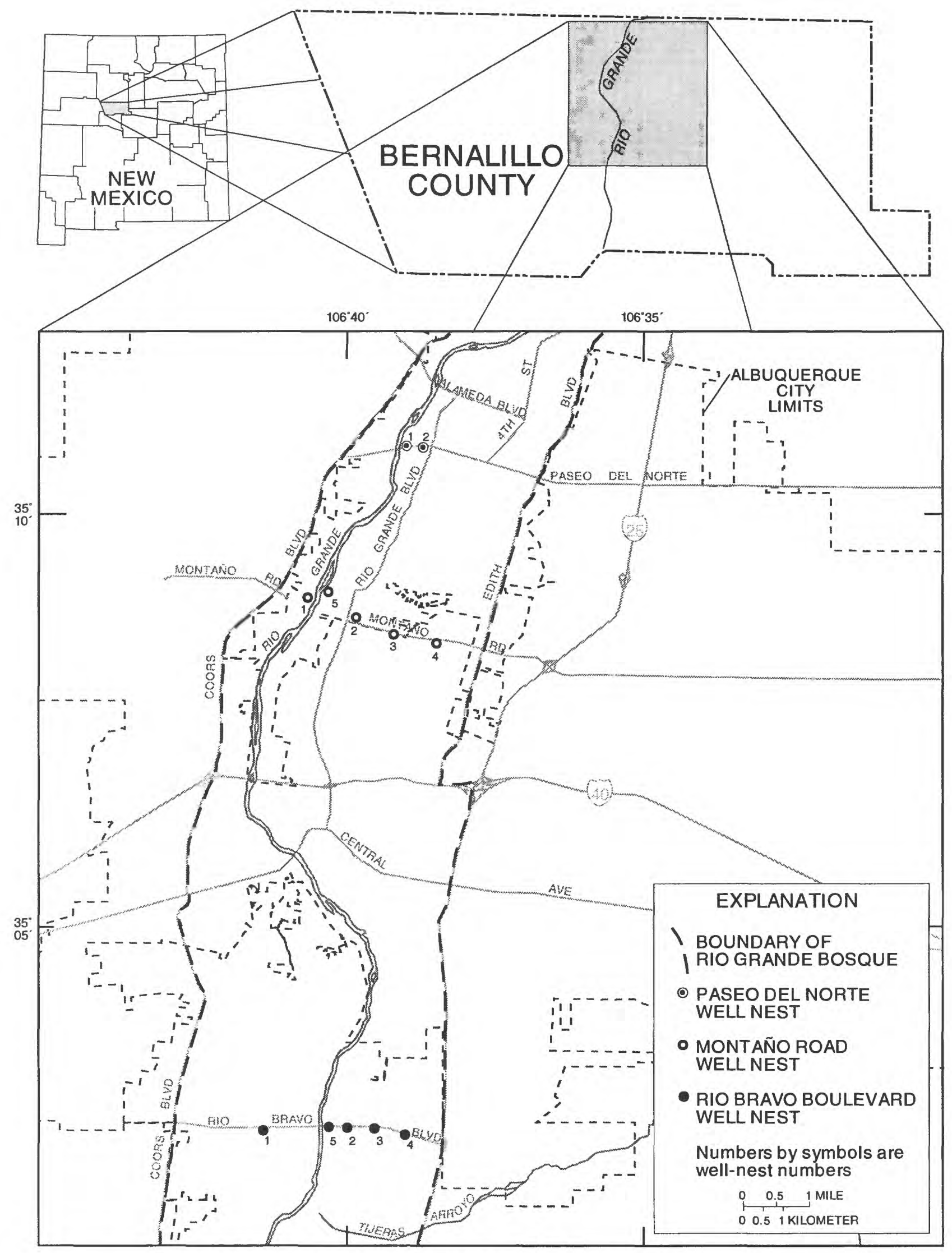

Figure 1.--Location of study area and well nests. 


\section{Well-Numbering System}

The locations of observation wells located outside of land-grant areas are specified by latitude and longitude to the nearest second and by a local identifier that is based on the publicland survey. The local identifier includes township and range followed by quarter-section subdivisions from largest to smallest. The order of the quarter-section subdivisions is opposite of that used in the public-land survey. A sequence letter is added to make the identifier unique in the U.S. Geological Survey data base. As illustrated in the following diagram, the public-land survey description of the site indicated by the dot is SE $1 / 4$ SE $1 / 4 \mathrm{NW} 1 / 4 \mathrm{sec} .08, \mathrm{~T}$. $09 \mathrm{~N}$., R. 03 E., which is denoted by the local identifier 09N.03E.08.144. If the observation well is the third well at that location, the sequence letter is $\mathrm{C}$, and the complete identifier is 09N.03E.08.144C. Locations of observation wells that are within land grants, and thus are not included in the public-land survey, are specified by latitude and longitude to the nearest second and the land-grant name is used as the local identifier.

Sections within a township

R. 03 E.
Quarter-section subdivisions

within a section

Sec. 08

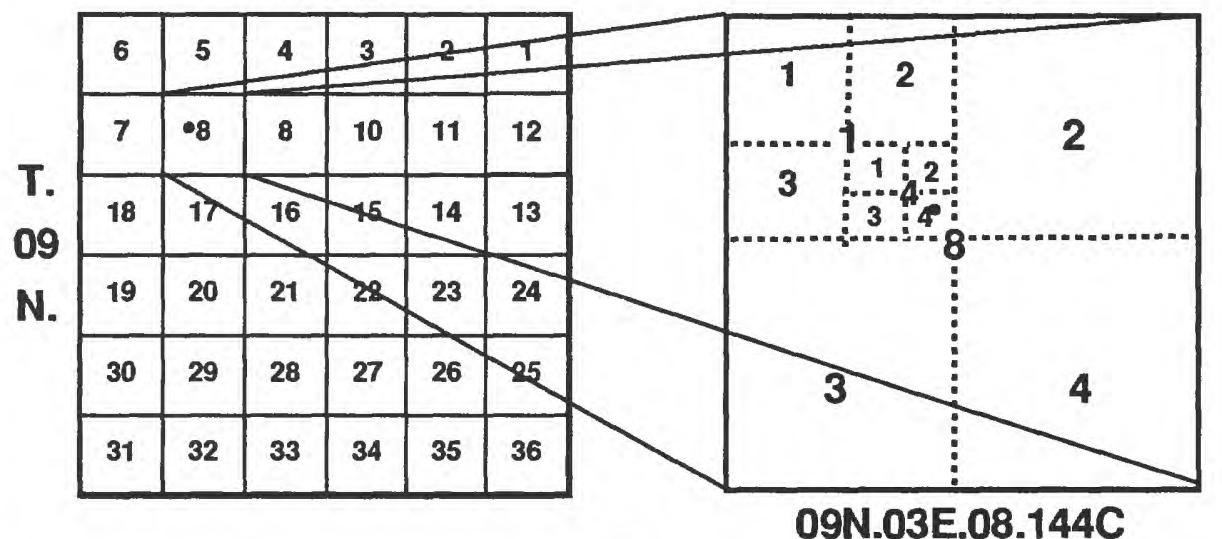

Figure 2.--Well-numbering system for New Mexico. 


\section{Description of the Study Area and Wells}

The study area is that reach of the Rio Grande Valley that is between Paseo del Norte and Rio Bravo Boulevard and bounded on the west by Coors Boulevard and on the east by Edith Boulevard north of Interstate 40 and by Interstate 25 south of Interstate 40 . This area is largely within the city limits of Albuquerque, though portions do include unincorporated areas of Bernalillo County and several small incorporated areas. The study area is located in the Albuquerque Basin, a large, complex deposit of alluvial and volcanic rocks bounded by regional faults of the Rio Grande Rift; a complete description of the basin (hydrology and geology) can be found in Thorn and others (1993). Ground-water recharge is generally from the Rio Grande, which flows through the approximate center of the basin, and from infiltration of precipitation in uplifted areas to the north and east of the basin (Thorn and others, 1993). These ground-water sources originate on and in different sediments and rock types resulting in variation in water quality in the basin/aquifer system (Anderholm, 1988).

Three east-west sections consisting of 12 observation-well nests were installed west of Interstate 25 paralleling three roads: Paseo del Norte, Montaño Road, and Rio Bravo Boulevard (fig. 1). Two well nests lie along Paseo del Norte, five well nests along Montaño Road, and five well nests along Rio Bravo Boulevard. Each nest includes three wells, completed at shallow, medium, and deep depths (table 1). The observation wells are completed in unconsolidated Quaternary alluvial deposits and Pleistocene sediments of the Santa Fe Group composed dominantly of fine- to very coarse grained quartz litharenite sand with interbeds of clayey, silty, or gravelly sand; silty or sandy clay; and sandy gravel. Wells were completed with a 5- to 10-foot screened interval that is isolated from the rest of the borehole by cement grout. Installation details for eight of the well nests along Montaño Road and Rio Bravo Boulevard were described by Anderholm and Bullard (1987). The other four well nests were installed in a similar manner. 


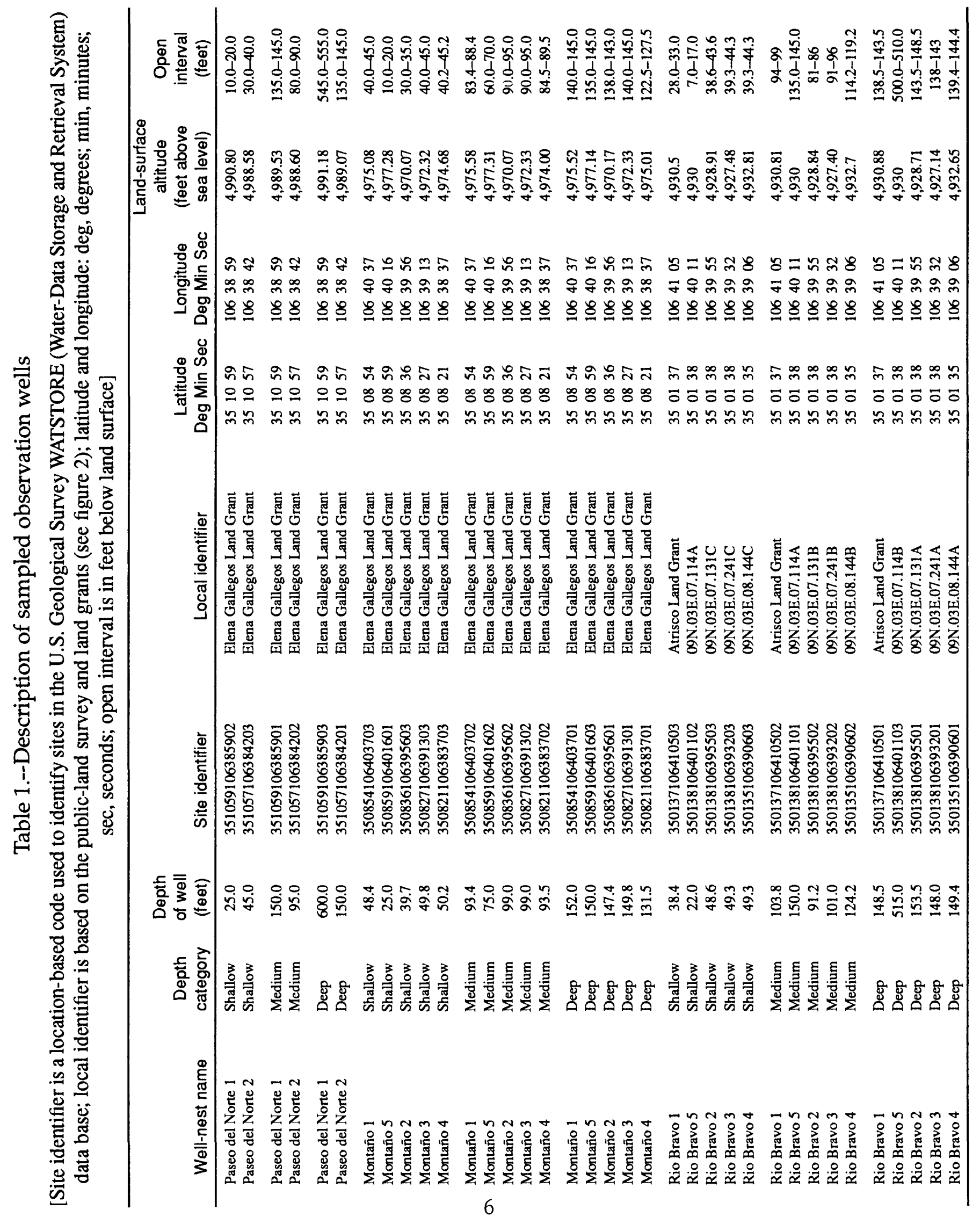




\section{DATA-COLLECTION METHODS}

Water samples were collected once from each well for chemical analysis. Methods used for the collection, preparation, and analyses are described below.

\section{Sample-Collection Methods}

Prior to sampling, all wells were purged by withdrawing a minimum of three casing volumes of water. Wells were purged using either a submersible, centrifugal, or air-operated bladder pump depending on the depth to water and the capacity of the well to produce water. The submersible pump was used on the Paseo del Norte 1 and 2, Montaño 2, 3, and 4, and Rio Bravo 3 and 4 well nests; the centrifugal pump was used on the Montaño 1 and 5 and Rio Bravo 5 well nests; and the air-lift pump was used on the Rio Bravo 1 and 2 well nests. Temperature and specific conductance were measured during purging at 2- to 15-minute intervals. When temperature and specific-conductance values stabilized, the water was considered to be representative of formation water.

Most water samples were collected using a 1-liter teflon bailer. The bailer was washed with liquinox soap and rinsed three times with deionized water before each well was sampled. Two bailers were used to collect samples from the first sampled well, which was the shallow well in the Rio Bravo 1 well nest. The 1-liter teflon bailer was used to collect samples to be analyzed for volatile organic carbon compounds; a 2-liter polyvinyl chloride bailer was used to collect all other samples. A polyethylene sheet was laid beside the well to prevent dirt and dust contamination of equipment and bottles during sampling. The bailer was lowered into the well, allowed to fill with water, and retrieved. Water from the first retrieval was used to wash and rinse the bailer. Water from the second retrieval was used to rinse sample bottles to be filled with unfiltered water. Water from subsequent retrievals of the bailer from the well was used to fill sample bottles. After direct filled (no rinse) bottles were filled, rinsed bottles for unfiltered samples were filled. Finally, a 2-liter or 1-gallon polyethylene bottle was filled to be used for filtered samples, alkalinity, $\mathrm{pH}$, and specific-conductance measurements. Latex or vinyl gloves were worn for sampling and preserving samples. The gloves were changed after each well was sampled and between use of different sample preservatives.

Two quality-assurance blank samples were prepared after laboratory determinations of volatile organic carbon compounds indicated the presence of toluene in some samples. An equipment blank was prepared on April 1, 1994, by filling the sample vial with organic-carbonfree water that had been passed through the sampling equipment. An ambient blank was prepared on April 4, 1994, by filling a sample vial at the Paseo del Norte 2 well nest with organiccarbon-free water.

\section{Sample-Preparation Methods}

Procedures used for preparation and preservation of the ground-water samples are listed in table 2. After samples were collected using the teflon bailer, water for the filtered samples was drawn through silicone tubing in a peristaltic pump, then pumped through a 0.45 -micron cartridge filter. About 1 liter of deionized water was pumped through the tube and filter before 
filtering the sample water. Vials for volatile organic carbon determination and bottles for total organic carbon determination were not rinsed but were filled directly allowing as little turbulence as possible. The gallon bottles and bottles for unfiltered, unacidified samples were rinsed three times with bailed well water before filling. All bottles for filtered samples were rinsed with filtered well water three times before filling (Timme, 1994). All samples were iced and shipped overnight express to the U.S. Geological Survey National Water Quality Laboratory (NWQL) in Arvada, Colorado.

Table 2.--Field procedures for preparation and preservation of water samples for laboratory analysis

[ $\mu$, micron; ml, milliliter; ${ }^{\circ} \mathrm{C}$, degrees Celsius. From Timme, 1994]

\begin{tabular}{|c|c|c|c|}
\hline Constituents to be analyzed & Filter type used & Collection bottle type & Preservation method \\
\hline $\begin{array}{l}\text { Major cations and trace elements, } \\
\text { dissolved except mercury }\end{array}$ & $\begin{array}{l}0.45-\mu \text { cartridge } \\
\text { filter }\end{array}$ & $\begin{array}{l}2250-\mathrm{ml} \text { acid-rinsed } \\
\text { polyethylene }\end{array}$ & $1 \mathrm{ml}$ nitric acid per $250-\mathrm{ml}$ sample \\
\hline Major anions, dissolved & $\begin{array}{l}0.45-\mu \text { cartridge } \\
\text { filter }\end{array}$ & $\begin{array}{l}1500 \text {-ml nonacid-rinsed } \\
\text { polyethylene }\end{array}$ & None \\
\hline Nutrients, dissolved & $\begin{array}{l}0.45-\mu \text { cartridge } \\
\text { filter }\end{array}$ & $\begin{array}{l}1250 \text {-ml amber polyeth- } \\
\text { ylene }\end{array}$ & $\begin{array}{l}1 \mathrm{ml} 10^{-4} \text { molar mercuric chloride } \\
\text { sodium chloride, chilled to } 4 \\
{ }^{\circ} \mathrm{C}\end{array}$ \\
\hline Mercury, dissolved & $\begin{array}{l}0.45-\mu \text { cartridge } \\
\text { filter }\end{array}$ & 1 125-ml baked glass & $\begin{array}{l}5 \mathrm{ml} \text { nitric acid/potassium dichro- } \\
\text { mate ampoule }\end{array}$ \\
\hline $\begin{array}{l}\text { Laboratory alkalinity, } \mathrm{pH} \text {, and } \\
\text { specific conductance }\end{array}$ & Unfiltered & $\begin{array}{l}2 \text { 250-ml nonacid- } \\
\text { rinsed polyethylene }\end{array}$ & None \\
\hline $\begin{array}{l}\text { Volatile organic carbon com- } \\
\text { pounds }\end{array}$ & Unfiltered & $\begin{array}{l}3 \text { 40-ml amber glass } \\
\text { septa vials }\end{array}$ & Chilled to $4{ }^{\circ} \mathrm{C}$ \\
\hline Total organic carbon & Unfiltered & 1 125-ml baked glass & Chilled to $4{ }^{\circ} \mathrm{C}$ \\
\hline
\end{tabular}

\section{Analytical Methods}

All laboratory determinations were done by the NWQL using standard methods described in Fishman and Friedman (1989). Methods used for total organic carbon and inorganic determinations are listed in table 3 . The volatile organic compounds listed in table 4 were determined using a method similar to U.S. Environmental Protection Agency method 524.2 (U.S. Environmental Protection Agency, 1988). Volatile organic compounds were purged from the water sample, and the purged compound types and concentrations were determined using a gas chromatograph with a mass spectrometric detector. Water $\mathrm{pH}$, specific conductance, and alkalinity were measured on site and in the laboratory. Alkalinity was measured on site by an incremental titration (Knapton, 1985) using $0.1639-\mathrm{N}$ sulfuric acid on a 50-milliliter aliquot of unfiltered sample. All concentrations, except organic carbon and toluene, are dissolved. 


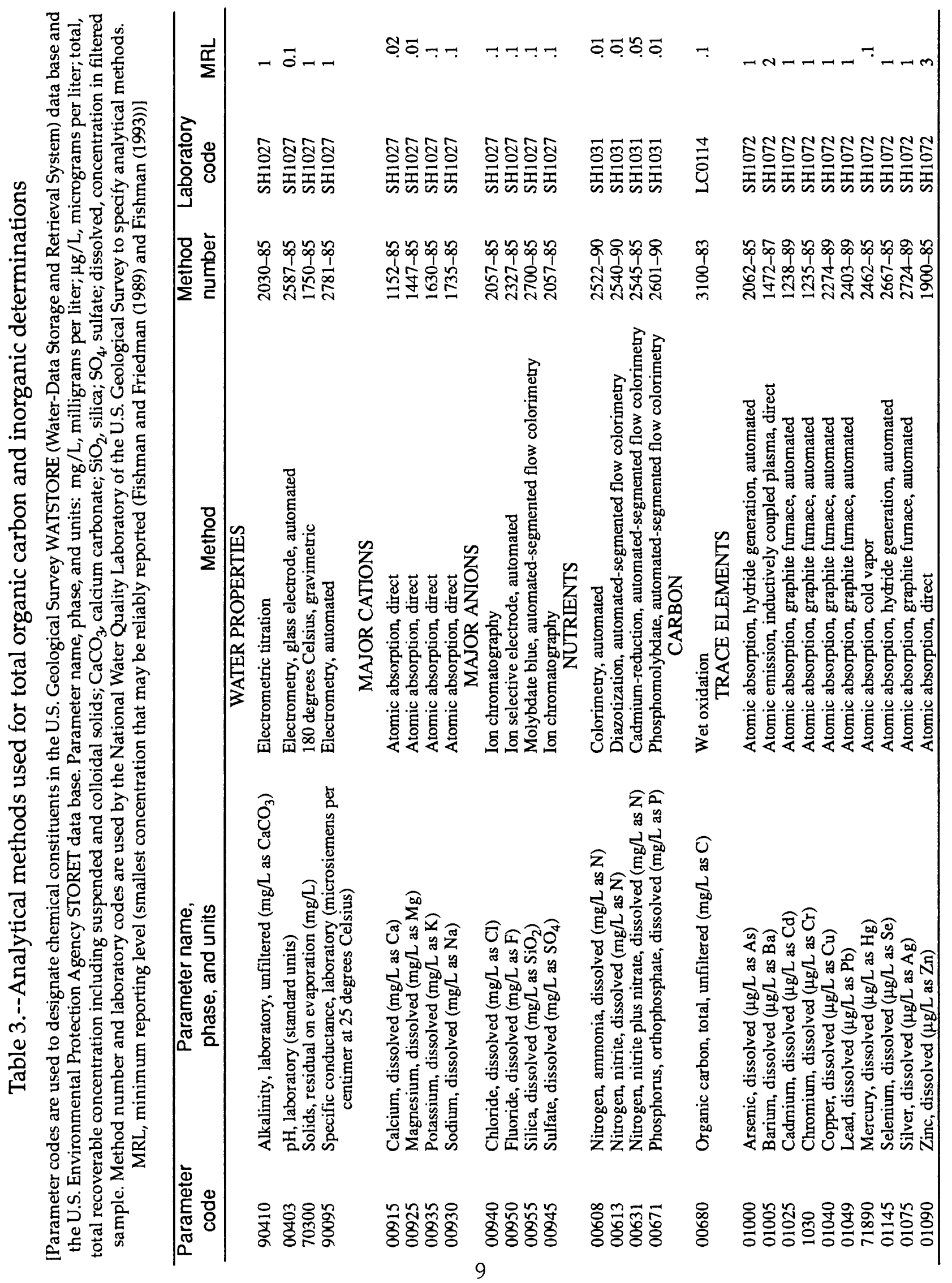


Table 4.-Volatile organic compounds for which water samples were analyzed

[Parameter codes designate chemical constituents in the U.S. Geological Survey WATSTORE (Water-Data Storage and Retrieval System) data base. MRL, minimum reporting level (smallest concentration that may be reliably reported); $\mu \mathrm{g} / \mathrm{L}$, micrograms per liter]

\begin{tabular}{|c|c|c|c|c|c|}
\hline $\begin{array}{l}\text { Parameter } \\
\text { code }\end{array}$ & Compound name & $\begin{array}{c}M R L \\
(\mu g / L)\end{array}$ & $\begin{array}{c}\text { Parameter } \\
\text { code }\end{array}$ & Compound name & $\begin{array}{l}\text { MRL } \\
(\mu g / L)\end{array}$ \\
\hline 77275 & 1,2-Chlorotoluene & 0.2 & 32104 & Bromoform & 0.2 \\
\hline 77277 & 1,4-Chlorotoluene & 0.2 & 77342 & n-Butylbenzene & 0.2 \\
\hline 34576 & 2-Chloroethylvinylether & 1 & 77350 & sec-Butylbenzene & 0.2 \\
\hline 77651 & 1,2-Dibromoethane & 0.2 & 32102 & Carbon tetrachloride & 0.2 \\
\hline 34536 & 1,2-Dichlorobenzene & 3 & 34301 & Chlorobenzene & 0.2 \\
\hline 34566 & 1,3-Dichlorobenzene & 0.2 & 32105 & Chlorodibromomethane & 0.2 \\
\hline 34571 & 1,4-Dichlorobenzene & 0.2 & 34311 & Chloroethane & 0.2 \\
\hline 34496 & 1,1-Dichloroethane & 0.2 & 32106 & Chloroform & 0.2 \\
\hline 32103 & 1,2-Dichloroethane & 0.2 & 34418 & Chloromethane & 0.2 \\
\hline 34501 & 1,1-Dichlorethylene & 0.2 & 82625 & Dibromochloropropane & 1.0 \\
\hline 77093 & cis-1,2-Dichloroethene & 0.2 & 30217 & Dibromomethane & 0.2 \\
\hline 34546 & trans-1,2-Dichloroethene & 0.2 & 32101 & Dichlorobromomethane & 0.2 \\
\hline 34541 & 1,2-Dichloropropane & 0.2 & 77128 & Dichlorodifluoromethane & 0.2 \\
\hline 77173 & 1,3-Dichloropropane & 0.2 & 34371 & Ethylbenzene & 0.2 \\
\hline 77170 & 2,2-Dichloropropane & 0.2 & 3970 & Hexachlorobutadiene & 0.2 \\
\hline 77168 & 1,1-Dichloropropene & 0.2 & 77223 & Isopropylbenzene & 0.2 \\
\hline 34704 & cis-1,3-Dichloropropene & 0.2 & 77356 & p-Isopropyltoluene & 0.2 \\
\hline 34699 & trans-1,3-Dichloropropene & 0.2 & 34413 & Methylbromide & 0.2 \\
\hline 77562 & 1,1,1,2-Tetrachloroethane & 0.2 & 34423 & Methylene chloride & 0.2 \\
\hline 34516 & 1,1,2,2-Tetrachloroethane & 0.2 & 78032 & Methyltertbutylether & 1 \\
\hline 77613 & 1,2,3-Trichlorobenzene & 0.2 & 34696 & Naphthalene & 0.2 \\
\hline 34551 & 1,2,4-Trichlorobenzene & 0.2 & 77224 & n-Propylbenzene & 0.2 \\
\hline 34506 & 1,1,1-Trichloroethane & 0.2 & 77128 & Styrene & 0.2 \\
\hline 34511 & 1,1,2-Trichloroethane & 0.2 & 77353 & Tertbutylbenzene & 0.2 \\
\hline 77443 & 1,2,3-Trichloropropane & 0.2 & 34475 & Tetrachloroethylene & 0.2 \\
\hline 77222 & 1,2,4-Trimethylbenzene & 0.2 & 34010 & Toluene & 0.2 \\
\hline 77226 & 1,3,5-Trimethylbenzene & 0.2 & 77652 & Trichlorofluoroethane & 0.5 \\
\hline 34210 & Acrolein & 20 & 39180 & Trichloroethylene & 0.2 \\
\hline 34215 & Acrylonitrile & 20 & 34488 & Trichlorofluoromethane & 0.2 \\
\hline 34030 & Benzene & 0.2 & 39175 & Vinyl chloride & 0.2 \\
\hline 81555 & Bromobenzene & 0.2 & 81551 & Xylenes, ortho, meta, and para & 0.2 \\
\hline 77297 & Bromochloromethane & 0.2 & & & \\
\hline
\end{tabular}




\section{RESULTS OF CHEMICAL ANALYSES}

Results of water analyses for physical properties, major ions, nutrients, trace elements, and toluene are listed in table 5. Results are not listed for volatile organic compounds other than toluene because only toluene was detected above the minimum reporting levels shown in table 4. Since both the equipment blank and the ambient blank contained toluene, toluene concentrations may not be reliable. Distributions of element concentrations related to depth and distance are given in the following sections.

\section{Major Ions}

The chemical character of ground water in the shallow, medium, and deep wells sampled in this investigation is shown by water-quality diagrams in figures 3 through 5 . In these diagrams cation concentrations, in milliequivalents per liter (meq/L), are indicated by the horizontal axis extending left from the center axis; anion concentrations, in meq $/ \mathrm{L}$, are indicated by the horizontal axis extending to the right; dissolved-solids concentration is indicated by the area of the diagram. Water-quality types can be inferred from the overall shape of the diagram; dominant-ion concentrations will extend farthest from the central axis. Sodium plus potassium, magnesium, calcium, chloride plus fluoride, sulfate, and bicarbonate plus carbonate are shown on the water-quality diagrams. In the following discussions water types that are composed of pairs (such as sodium plus potassium) are described using only the first ion of the above ion pairs.

Water from shallow wells is a calcium bicarbonate type except from Montaño 4, which is a calcium sulfate type, and Rio Bravo 3, which is a sodium calcium bicarbonate type. Water from Montaño 4 has the highest dissolved-solids concentration, 1,280 milligrams per liter (mg/L), of water from any well of any depth.

Several variations of water types are found in water from medium wells. Water from medium wells in the Paseo del Norte and Montaño sections is a calcium bicarbonate type except Montaño 1, which is a calcium sulfate bicarbonate type, and Montaño 3, which is a sodium calcium bicarbonate type. In the Rio Bravo section, water from Rio Bravo 1 is a sodium sulfate type; from Rio Bravo 5 is a sodium bicarbonate type; from Rio Bravo 2 and 3 is a sodium calcium bicarbonate type; and from Rio Bravo 4 is a calcium chloride sulfate type. Water from Montaño 4 and Rio Bravo 4 contains the highest dissolved-solids concentrations of the medium wells, 653 and $654 \mathrm{mg} / \mathrm{L}$, respectively.

Water quality varies in deep wells at the Montaño and Rio Bravo sections. Water from wells at the Paseo del Norte section is a calcium bicarbonate type. At the Montaño section, water from Montaño 1 is a calcium sulfate bicarbonate type; the other wells in the Montaño section have water of a calcium bicarbonate type. At the Rio Bravo section, Rio Bravo 1 and 5 contain water of a sodium sulfate type. Water from Rio Bravo 2 is a sodium bicarbonate type; from Rio Bravo 3 is a calcium sulfate type; and from Rio Bravo 4 is a calcium bicarbonate type. Water from Montaño 3 has a dissolved-solids concentration of $553 \mathrm{mg} / \mathrm{L}$, the highest from the deep wells. 


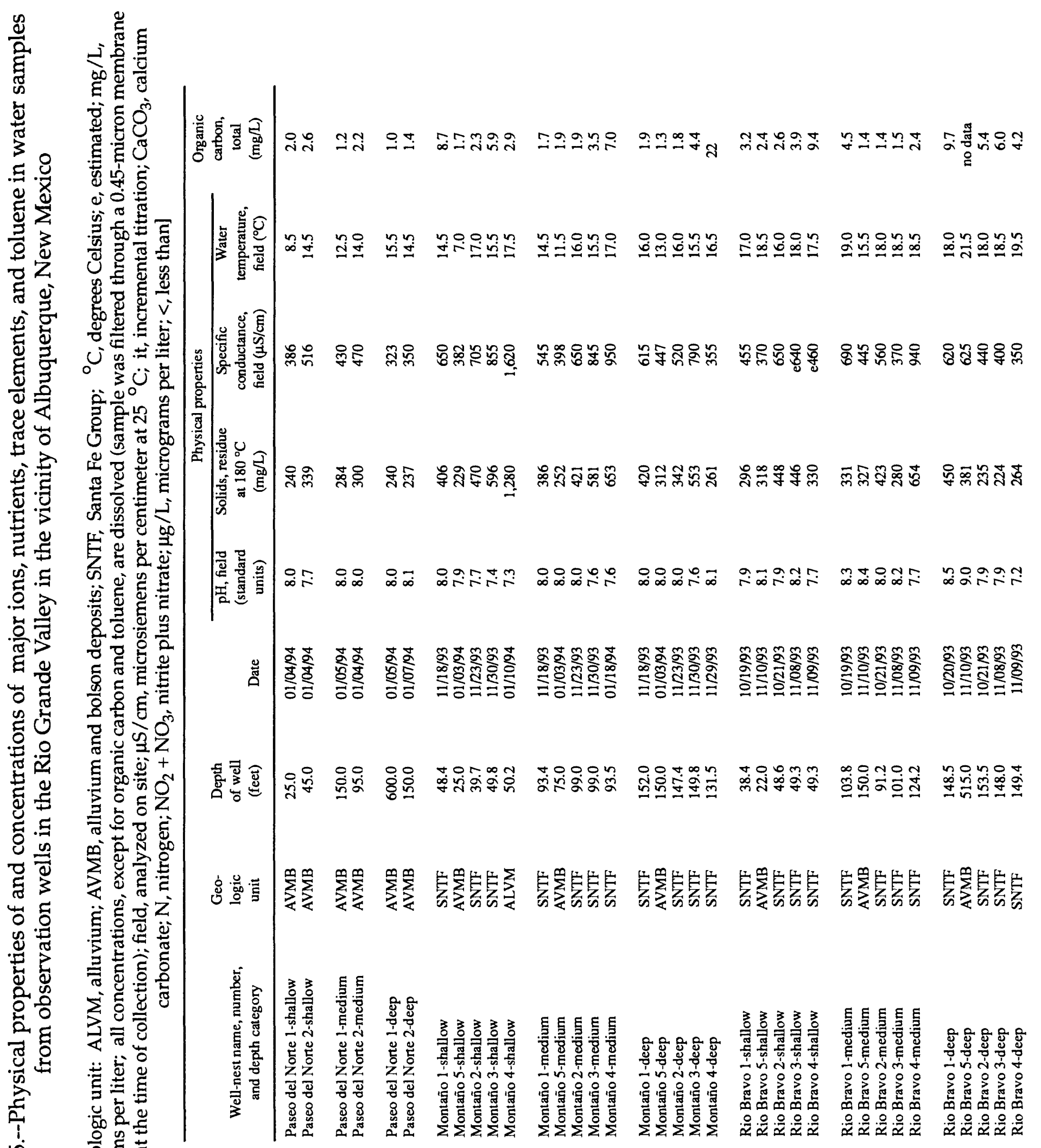




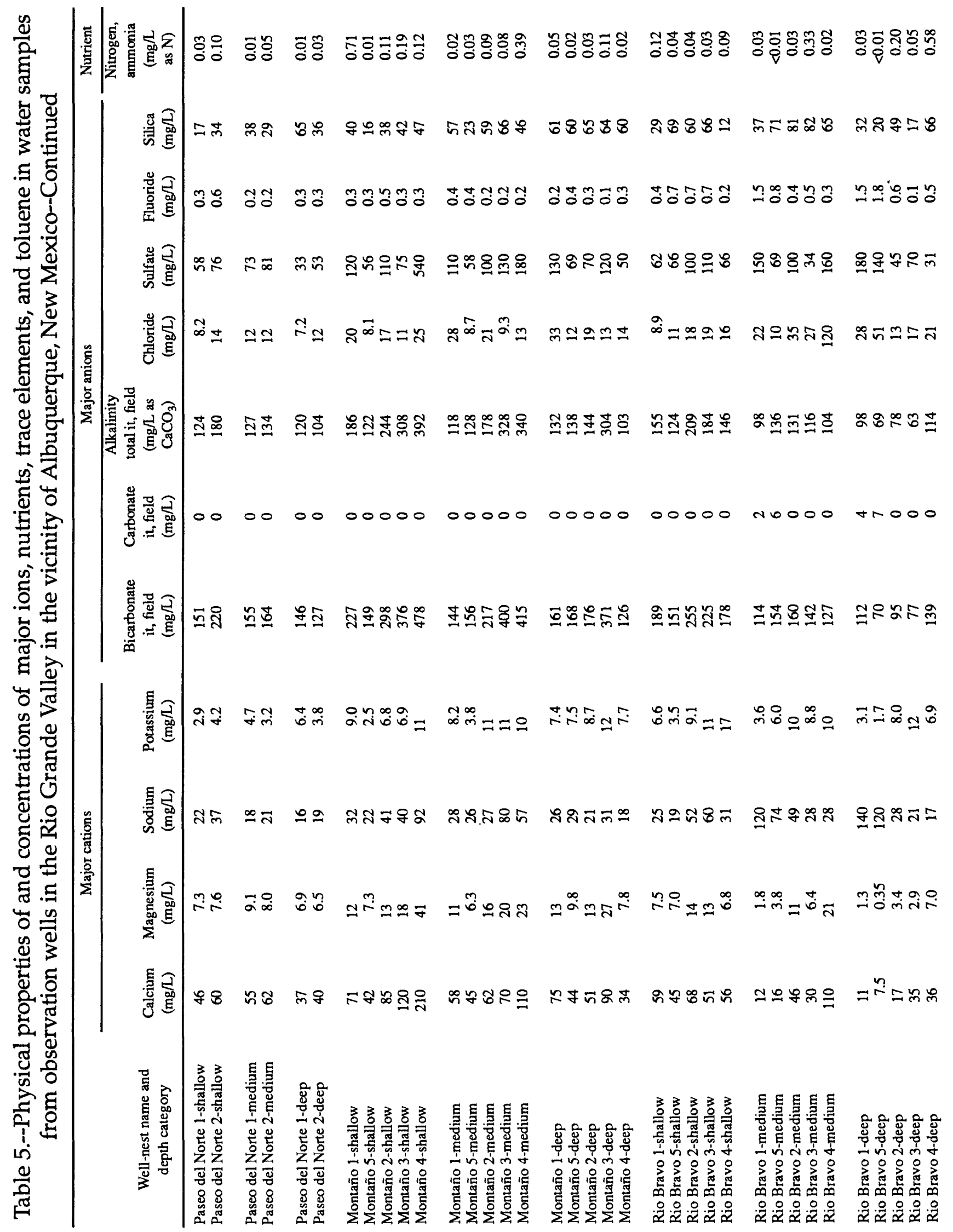




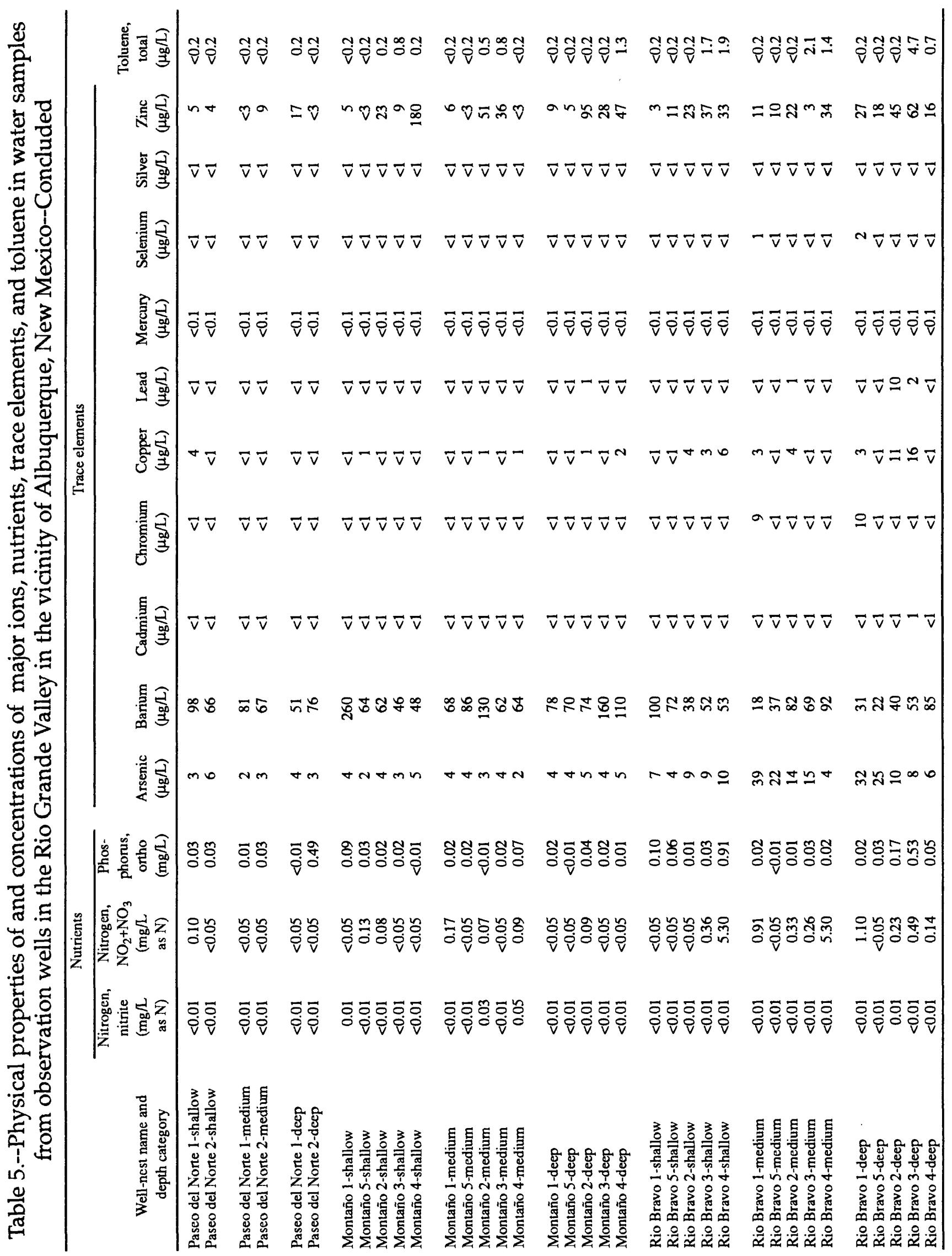




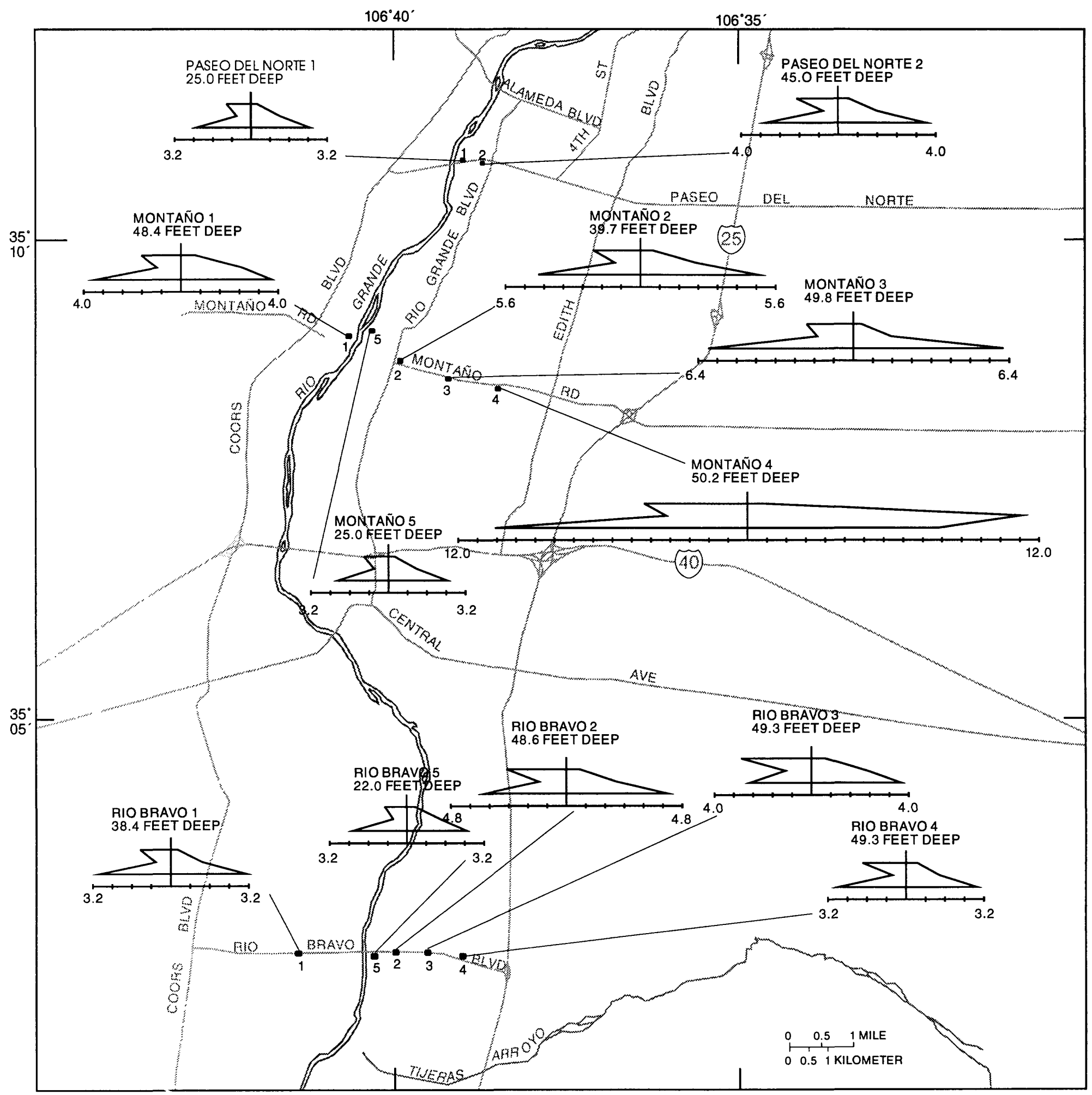

EXPLANATION

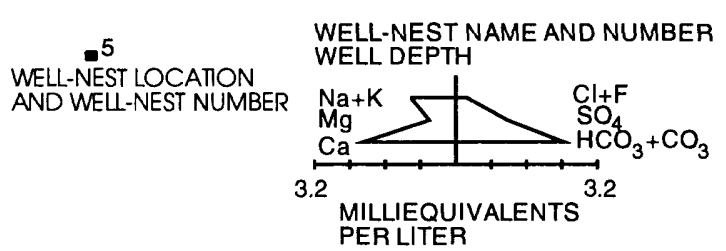

Figure 3.--Distribution of dissolved major-ion concentrations in shallow wells. 


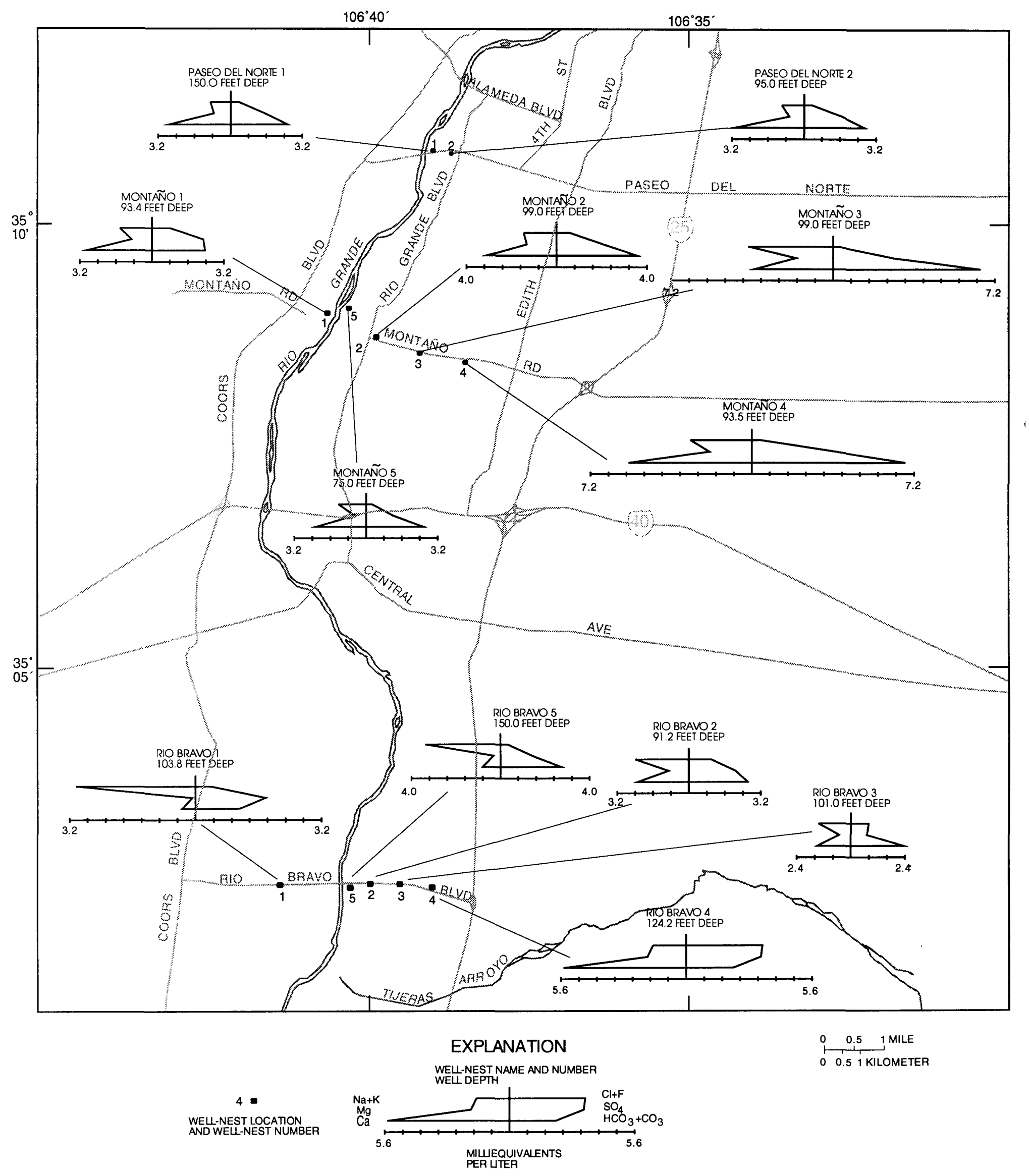

Figure 4.--Distribution of dissolved major-ion concentrations in medium wells. 


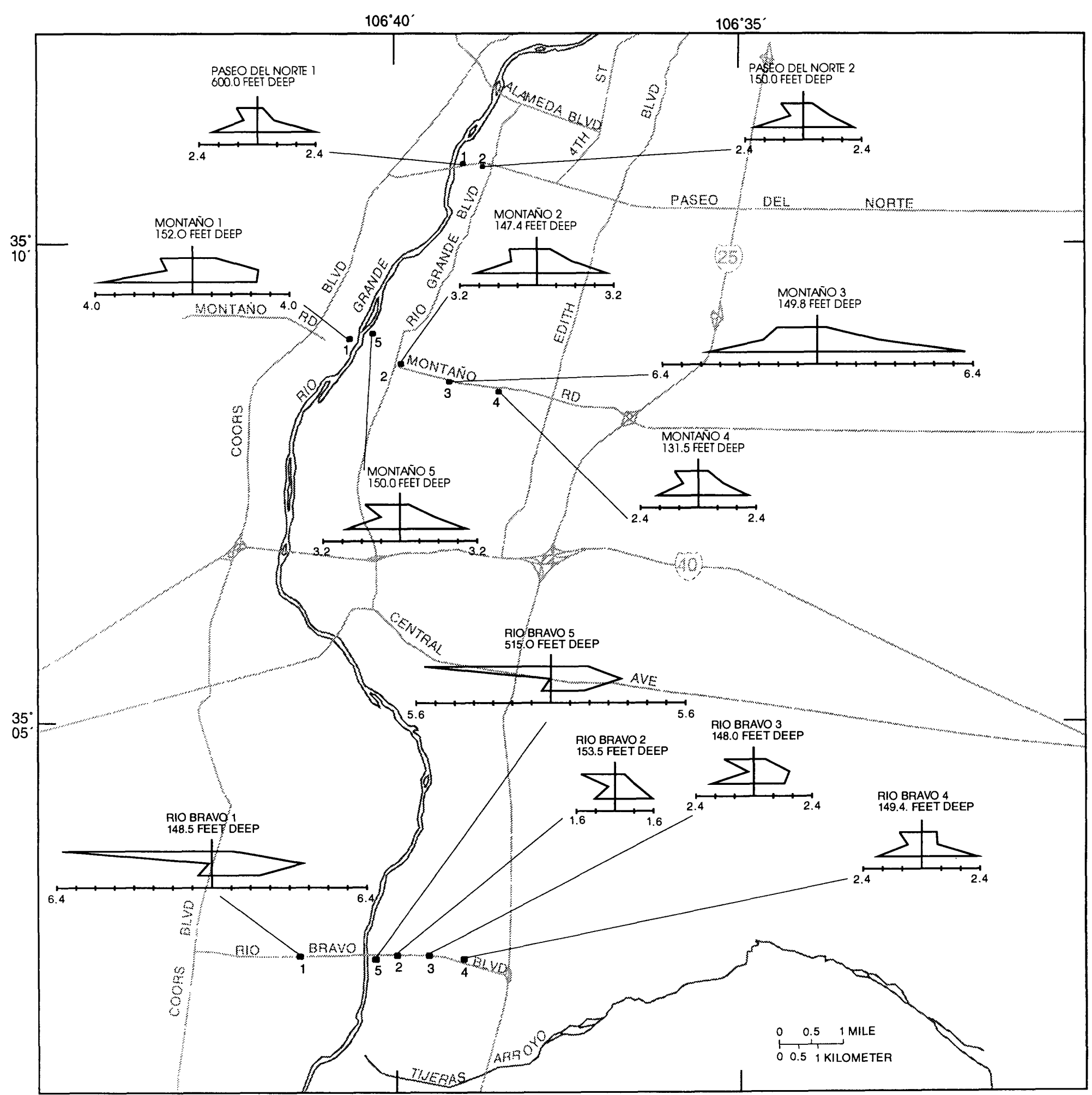

\section{EXPLANATION}

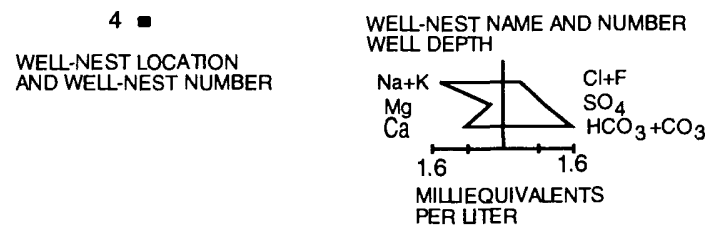

Figure 5.--Distribution of dissolved major-ion concentrations in deep wells. 


\section{Nutrients}

Distribution of nutrient concentrations at various depths along each of the three sections is shown in figures 6, 7, and 8. Ammonia, nitrite, nitrite plus nitrate, or orthophosphate concentrations were measured in water from each of the 36 wells.

Ammonia as nitrogen was detected in water from 34 wells. At the Paseo del Norte section ammonia was detected in all water samples. Measured ammonia concentrations ranged from $0.01 \mathrm{mg} / \mathrm{L}$ in the Paseo del Norte 1 medium and deep wells to $0.10 \mathrm{mg} / \mathrm{L}$ in the Paseo del Norte 2 shallow well. Nitrite was not detected in water from any Paseo del Norte wells. Nitrite plus nitrate as nitrogen was detected in only the Paseo del Norte 1 shallow well at a concentration of $0.10 \mathrm{mg} / \mathrm{L}$. Orthophosphate as phosphorus was detected in all but one of the Paseo del Norte wells--the Paseo del Norte 1 deep well. Measured concentrations of orthophosphate in the remaining wells ranged from $0.01 \mathrm{mg} / \mathrm{L}$ in the Paseo del Norte 1 medium well to $0.49 \mathrm{mg} / \mathrm{L}$ in the Paseo del Norte 2 deep well.

At the Montaño section ammonia as nitrogen was detected in all water samples. Measured ammonia concentrations ranged from $0.01 \mathrm{mg} / \mathrm{L}$ in water from the Montaño 5 shallow well to $0.71 \mathrm{mg} / \mathrm{L}$ in water from the Montaño 1 shallow well. Nitrite as nitrogen was detected in the Montaño 1 shallow, Montaño 2 medium, and Montaño 4 medium wells. Nitrite concentrations ranged from $0.01 \mathrm{mg} / \mathrm{L}$ in the Montaño 1 shallow well to $0.05 \mathrm{mg} / \mathrm{L}$ in the Montaño 4 medium well. Nitrite plus nitrate was detected in water from the Montaño 1 medium; Montaño 5 shallow; Montaño 2 shallow, medium, and deep; and Montaño 4 medium wells. Concentrations ranged from $0.07 \mathrm{mg} / \mathrm{L}$ in the Montaño 2 medium well to 0.17 in the Montaño 1 medium well. Orthophosphate as phosphorus was detected in water from all but three of the Montaño wells-the Montaño 5 deep, Montaño 2 medium, and Montaño 4 shallow wells. Measured orthophosphate concentrations ranged from $0.01 \mathrm{mg} / \mathrm{L}$ in the Montaño 4 deep well to $0.09 \mathrm{mg} / \mathrm{L}$ in the Montaño 1 shallow well.

At the Rio Bravo section ammonia as nitrogen was detected in water from all but two wells--the Rio Bravo 5 medium and deep wells. Measured ammonia concentrations in the remaining wells ranged from $0.02 \mathrm{mg} / \mathrm{L}$ in the Rio Bravo 4 medium well to $0.58 \mathrm{mg} / \mathrm{L}$ in the Rio Bravo 4 deep well. Nitrite as nitrogen was detected only in water from the Rio Bravo 2 deep well at a concentration $0.01 \mathrm{mg} / \mathrm{L}$. Nitrite plus nitrate was not detected in water from the Rio Bravo 1 shallow; Rio Bravo 5 shallow, medium, and deep; and Rio Bravo 2 shallow wells. Nitrite plus nitrate concentrations in water from the other wells ranged from $0.14 \mathrm{mg} / \mathrm{L}$ in the Rio Bravo 4 deep well to $5.30 \mathrm{mg} / \mathrm{L}$ in the Rio Bravo 4 shallow and medium wells. Orthophosphate as phosphorus was not detected in water from the Rio Bravo 5 medium well. Measured orthophosphate concentrations in water from the remaining wells ranged from $0.01 \mathrm{mg} / \mathrm{L}$ in the Rio Bravo 2 shallow and medium wells to $0.91 \mathrm{mg} / \mathrm{L}$ in the Rio Bravo 4 shallow well.

\section{Selected Trace Elements}

Distribution of selected trace-element concentrations at various depths along each of the three sections is shown in figures 9, 10, and 11. All water samples were analyzed for arsenic, barium, cadmium, chromium, copper, lead, mercury, selenium, silver, and zinc. Mercury and silver were not detected in any water samples and therefore are not shown on the graphs in figures 9 through 11. The greatest barium and zinc concentrations in general were detected in water from wells in the Montaño section, and the greatest arsenic, chromium, copper, lead, and selenium concentrations were in water from wells in the Rio Bravo section. 

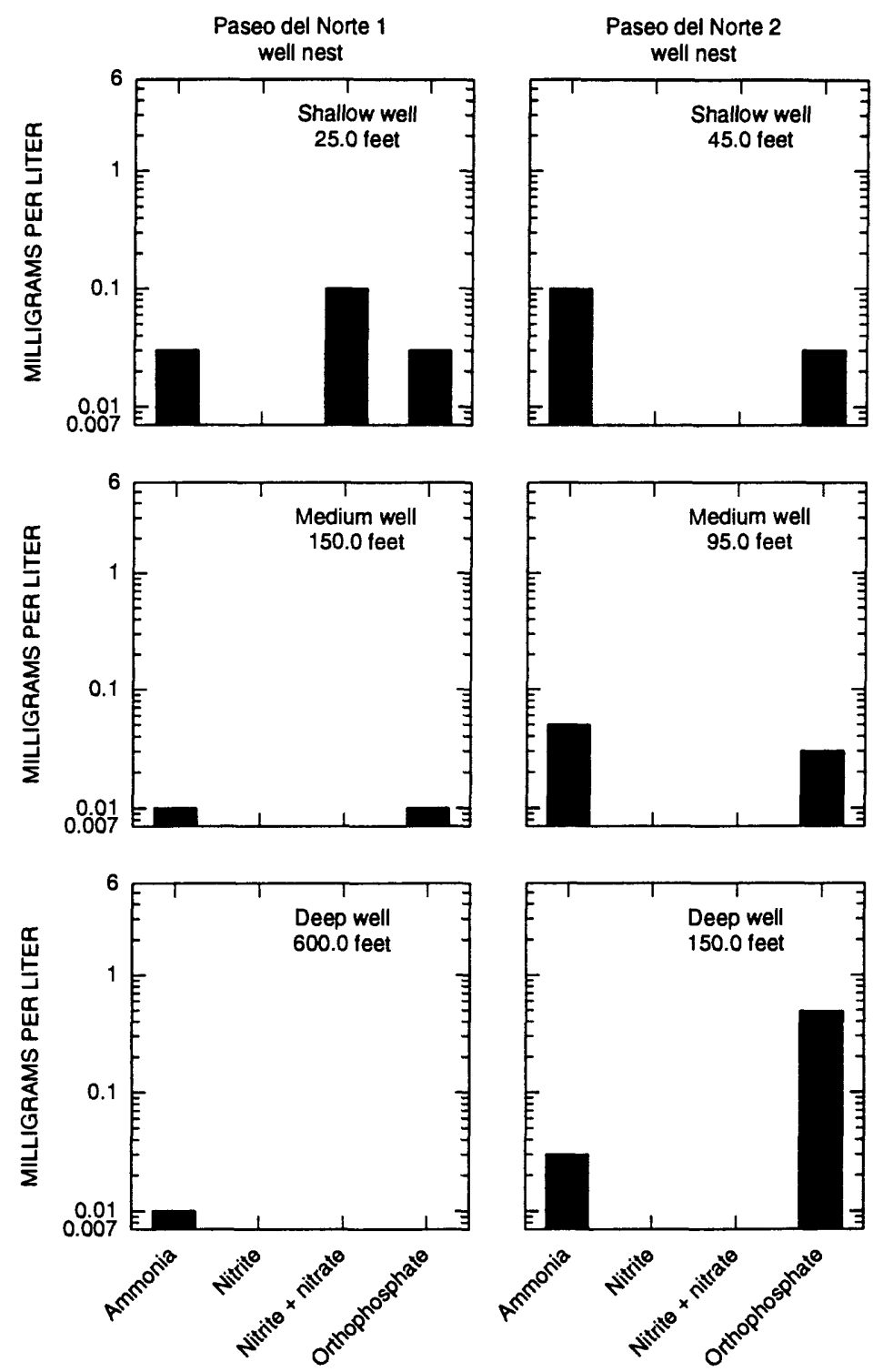

EXPLANATION

Ammonia, nitrite, and nitrite + nitrate reported as nitrogen. Orthophosphate reported as phosphorus
No bar Indicates analysis results were less than 0.01 milligram per liter minimum reporting level for nitrite and orthophosphate and 0.05 milligram per liter minimum reporting level for nitrite + nitrate

Figure 6.--Dissolved-nutrient concentrations in water from wells in the Paseo del Norte section. 

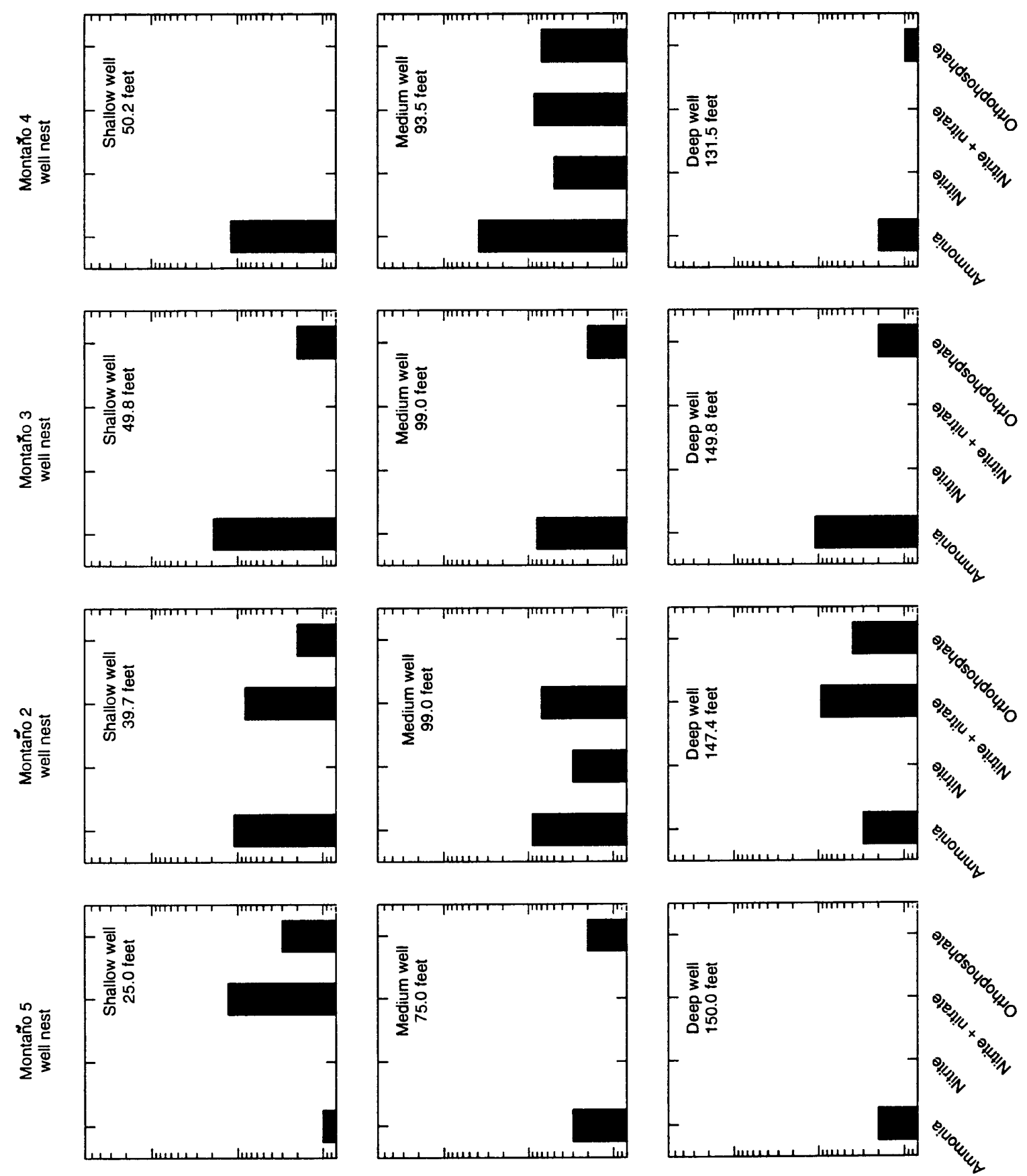

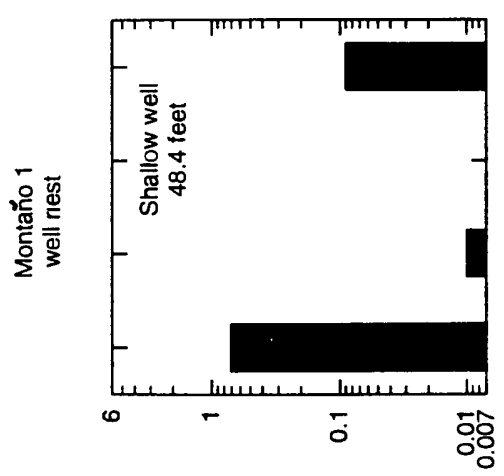

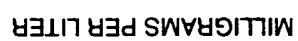

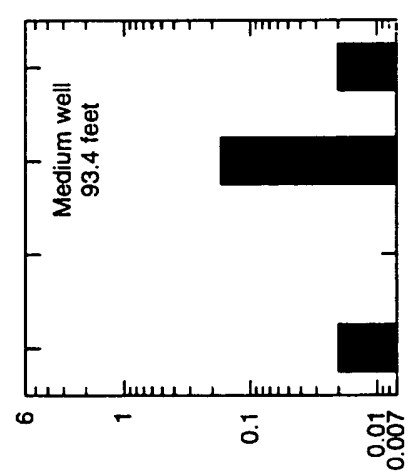

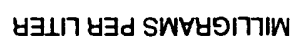

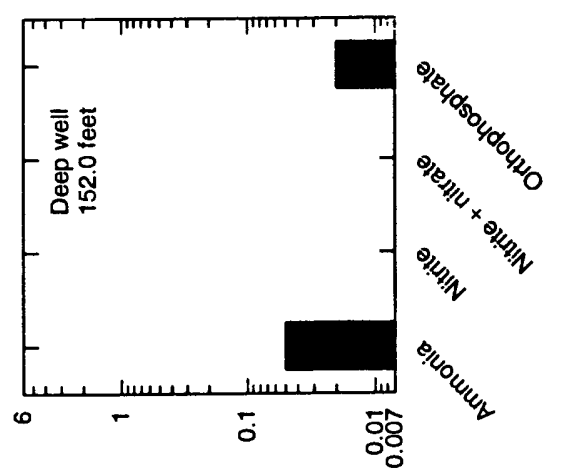

צᄏ1กษ 

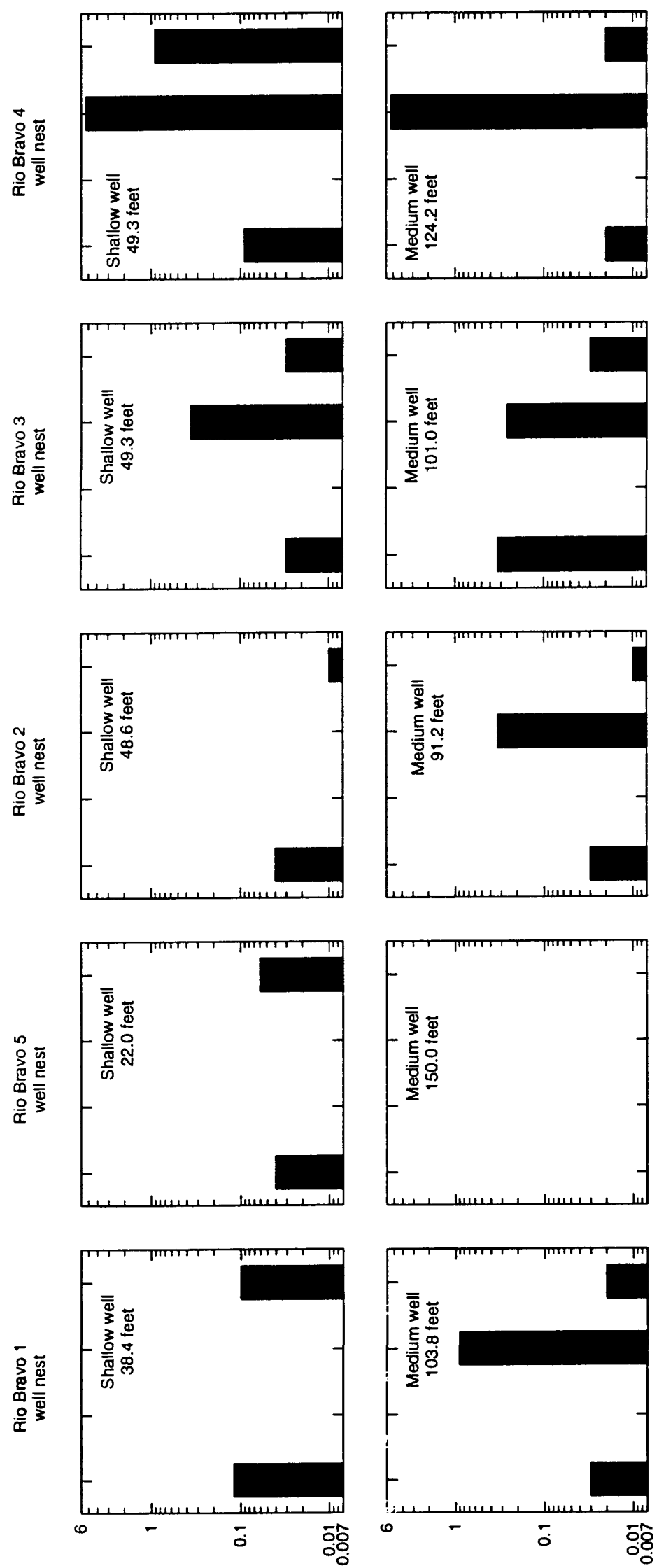

ษ

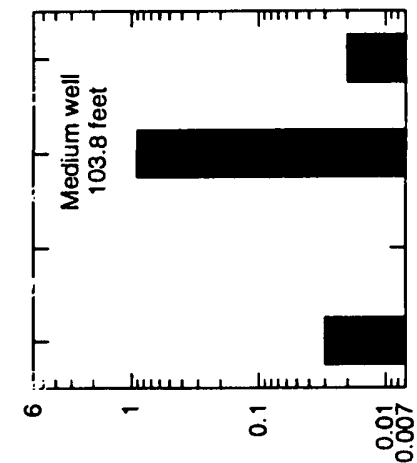

y
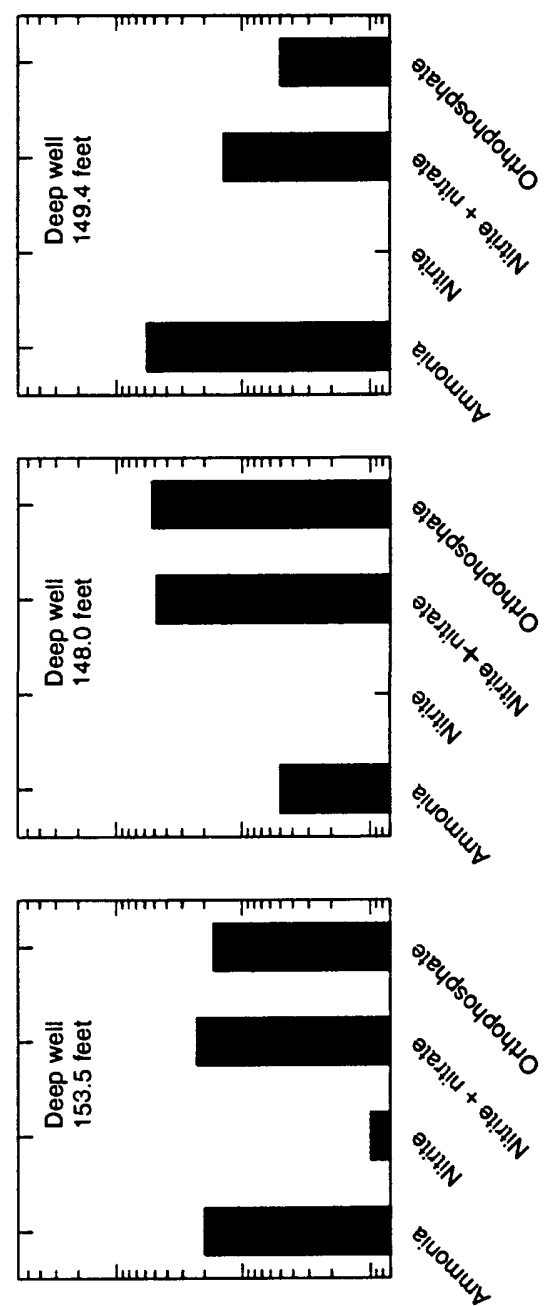

文

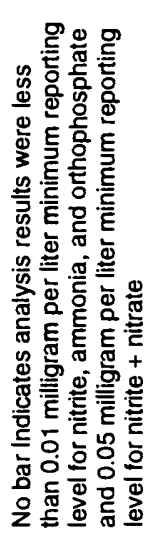

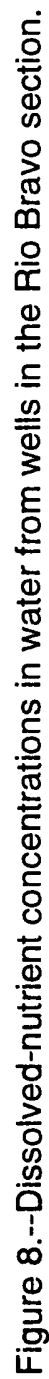

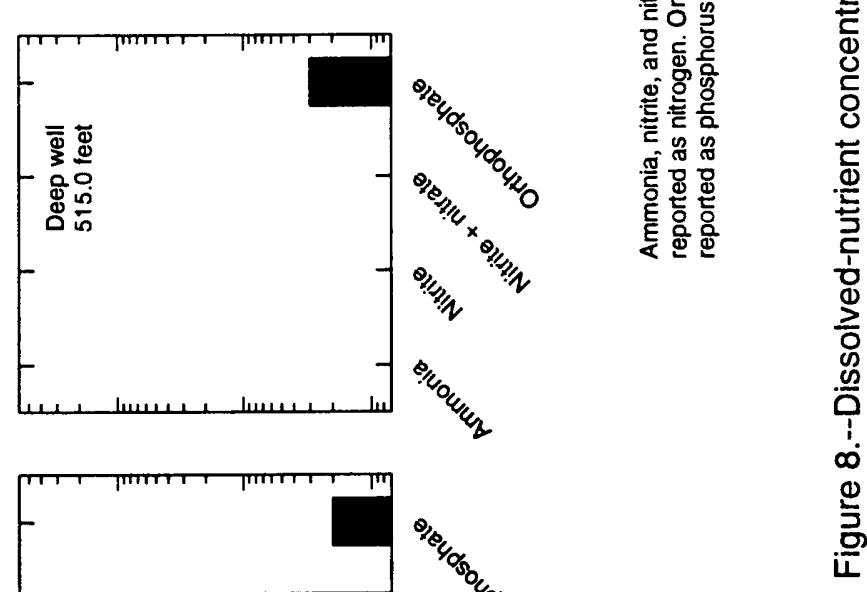

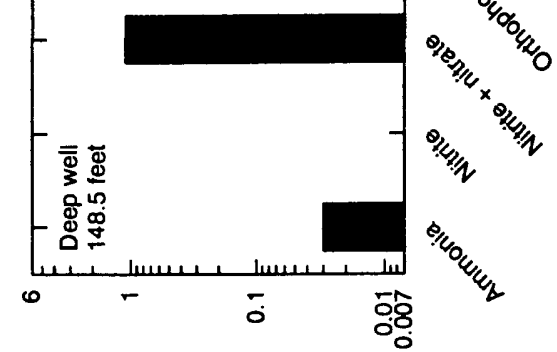

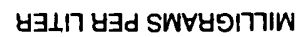


Arsenic was detected in water samples from all wells in the Paseo del Norte section. Concentrations ranged from 2 micrograms per liter $(\mu \mathrm{g} / \mathrm{L})$ in the Paseo del Norte 1 medium well to $6 \mu \mathrm{g} / \mathrm{L}$ in the Paseo del Norte 2 shallow well. Barium was detected in water from all Paseo del Norte wells. Concentrations ranged from $51 \mu \mathrm{g} / \mathrm{L}$ in the Paseo del Norte 1 deep well to $98 \mu \mathrm{g} / \mathrm{L}$ in the Paseo del Norte 1 shallow well. Cadmium and chromium were not detected in water from any Paseo del Norte wells. Copper was detected in water from the Paseo del Norte 1 shallow well at a concentration of $4 \mu \mathrm{g} / \mathrm{L}$. Lead and selenium were not detected in water from any Paseo del Norte wells. Zinc was detected in all Paseo del Norte wells except the Paseo del Norte 1 medium and Paseo del Norte 2 deep wells. Concentrations of zinc in water from the other wells ranged from $4 \mu \mathrm{g} / \mathrm{L}$ in the Paseo del Norte 2 shallow well to $17 \mu \mathrm{g} / \mathrm{L}$ in the Paseo del Norte 1 deep well.

Arsenic was detected in water from all wells in the Montaño section. Concentrations ranged from $2 \mu \mathrm{g} / \mathrm{L}$ in water from the Montaño 5 shallow and Montaño 4 medium wells to 5 $\mu \mathrm{g} / \mathrm{L}$ in water from the Montaño 2 deep and Montaño 4 shallow and deep wells. Barium was detected in water from all Montaño wells. Concentrations ranged from $46 \mu \mathrm{g} / \mathrm{L}$ in water from the Montaño 3 shallow well to $260 \mu \mathrm{g} / \mathrm{L}$ in the Montaño 1 shallow well. Water from the Montaño 2 medium, Montaño 3 deep, and Montaño 4 deep wells also contained a barium concentration greater than $100 \mu \mathrm{g} / \mathrm{L}$. Cadmium and chromium were not detected in water from any Montaño wells. Copper was detected in water from the Montaño 5 shallow, Montaño 2 medium and deep, and Montaño 4 medium and deep wells. Concentrations ranged from 1 to $2 \mu \mathrm{g} / \mathrm{L}$; the concentration of $2 \mu \mathrm{g} / \mathrm{L}$ was detected at the Montaño 4 deep well. Lead was detected only in water from the Montaño 2 deep well at a concentration of $1 \mu \mathrm{g} / \mathrm{L}$. Selenium was not detected in water from any Montaño wells. Zinc was detected in water from all Montaño wells except the Montaño 5 shallow and medium and Montaño 4 medium wells. Concentrations of zinc in water from the other wells ranged from $5 \mu \mathrm{g} / \mathrm{L}$ in the Montaño 1 shallow and Montaño 5 deep wells to $180 \mu \mathrm{g} / \mathrm{L}$ in the Montaño 4 shallow well.

Arsenic was detected in water from all wells in the Rio Bravo section. Concentrations ranged from $4 \mu \mathrm{g} / \mathrm{L}$ in water from the Rio Bravo 5 shallow and Rio Bravo 4 medium wells to 39 $\mu \mathrm{g} / \mathrm{L}$ in the Rio Bravo 1 medium well. Arsenic concentrations of $10 \mu \mathrm{g} / \mathrm{L}$ or greater were detected in water from the Rio Bravo 1 medium and deep, Rio Bravo 5 medium and deep, Rio Bravo 2 medium and deep, Rio Bravo 3 medium, and Rio Bravo 4 shallow wells. Barium was detected in water from all Rio Bravo wells. Concentrations ranged from $18 \mu \mathrm{g} / \mathrm{L}$ in the Rio Bravo 1 medium well to $100 \mu \mathrm{g} / \mathrm{L}$ in the Rio Bravo 1 shallow well. Cadmium was detected only in water from the Rio Bravo 3 deep well at a concentration of $1 \mu \mathrm{g} / \mathrm{L}$. Chromium was detected in water from the Rio Bravo 1 medium and deep wells at concentrations of 9 and $10 \mu \mathrm{g} / \mathrm{L}$, respectively. Copper was detected in water from the Rio Bravo 1 medium and deep; Rio Bravo 2 shallow, medium, and deep; Rio Bravo 3 shallow and deep; and Rio Bravo 4 shallow wells. Concentrations ranged from $3 \mu \mathrm{g} / \mathrm{L}$ in the Rio Bravo 1 medium and deep and Rio Bravo 3 shallow wells to $16 \mu \mathrm{g} / \mathrm{L}$ in the Rio Bravo 3 deep well. Lead was detected in water from the Rio Bravo 2 medium and deep and Rio Bravo 3 deep wells. Concentrations ranged from $1 \mu \mathrm{g} / \mathrm{L}$ in water from the Rio Bravo 2 medium well to $10 \mu \mathrm{g} / \mathrm{L}$ in the Rio Bravo 2 deep well. Selenium was detected in water from the Rio Bravo 1 medium and deep wells at concentrations of 1 and 2 $\mu \mathrm{g} / \mathrm{L}$, respectively. Zinc was detected in water from all wells in the Rio Bravo section. Concentrations ranged from $3 \mu \mathrm{g} / \mathrm{L}$ in the Rio Bravo 1 shallow and Rio Bravo 3 medium wells to $62 \mu \mathrm{g} / \mathrm{L}$ in the Rio Bravo 3 deep well. 


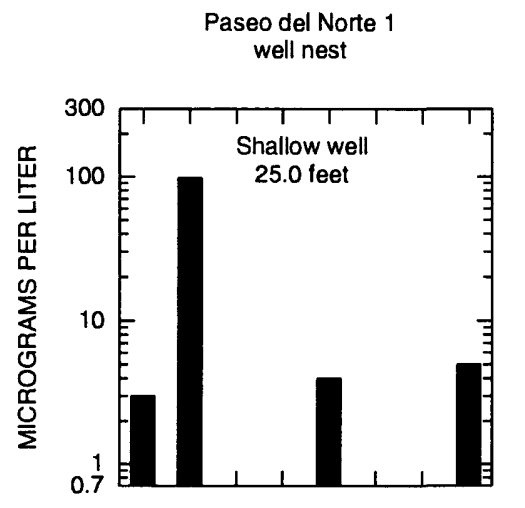

Paseo del Norte 2

well nest
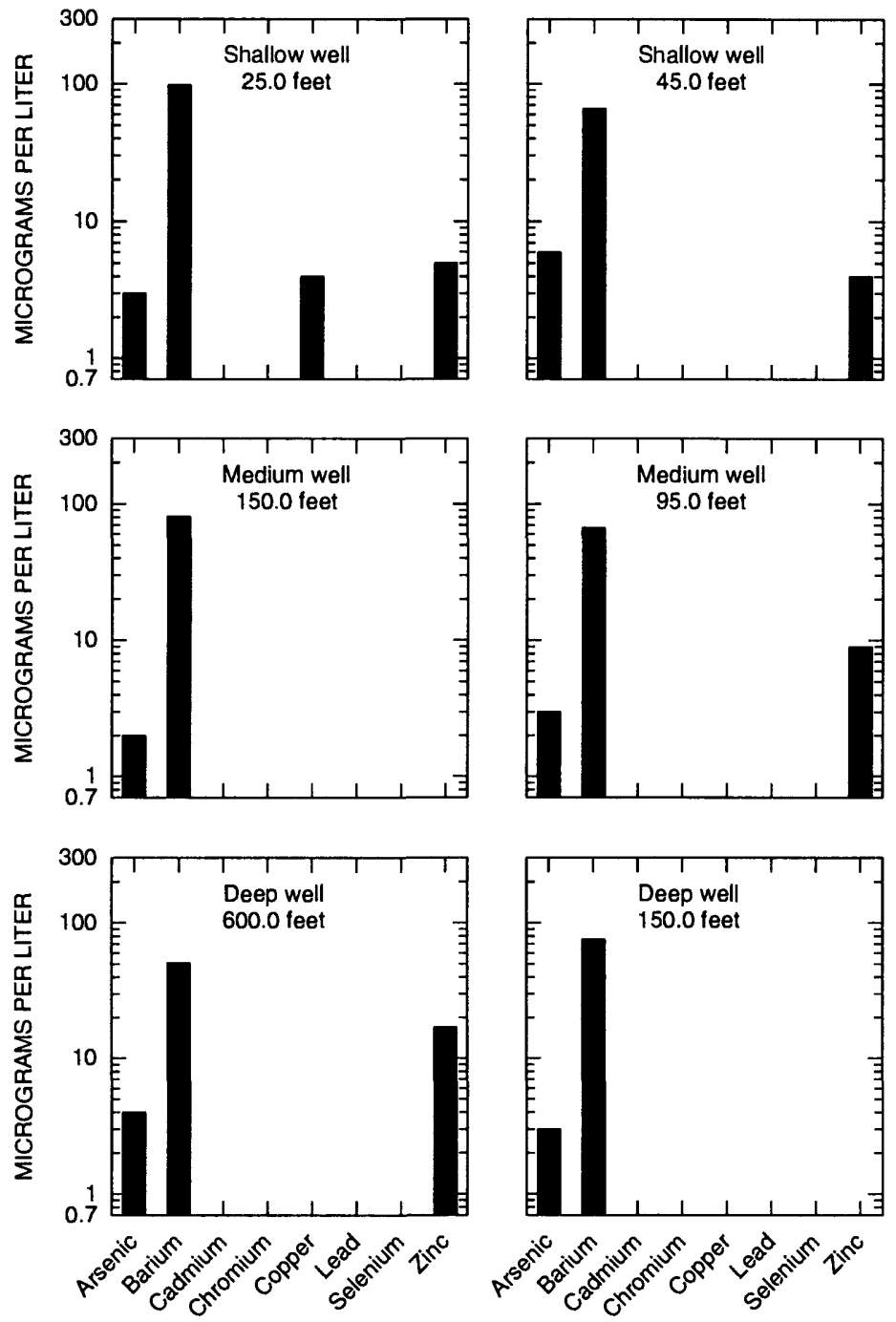

\title{
EXPLANATION
}

\begin{abstract}
No bar indicates analysis results were less than 1 microgram per liter minimum reporting level for cadmium, chromium, copper, lead, and selenium and 3
\end{abstract} micrograms per liter minimum reporting level for zinc

Figure 9.--Dissolved trace-element concentrations in water from wells in the Paseo del Norte section. 

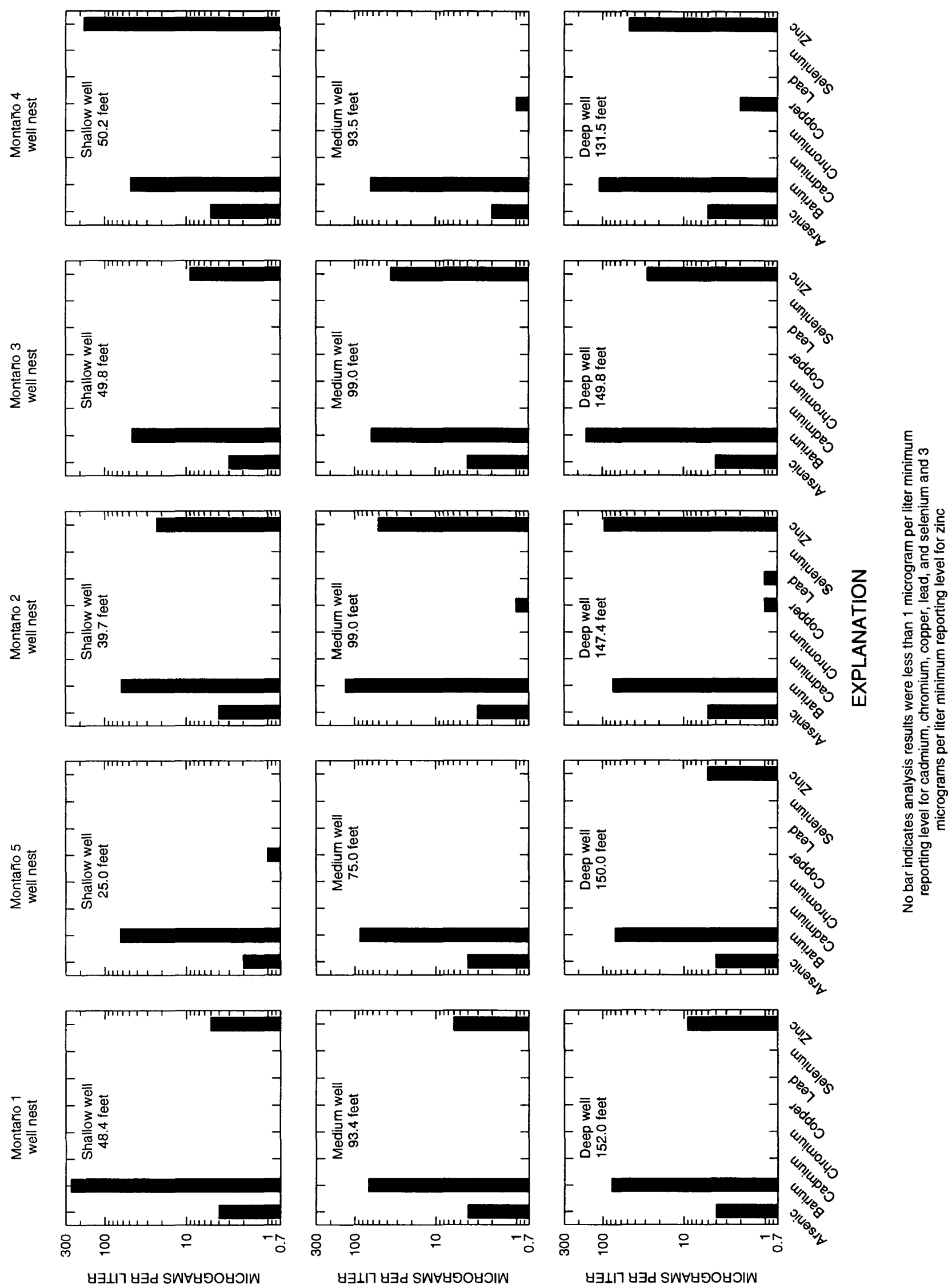

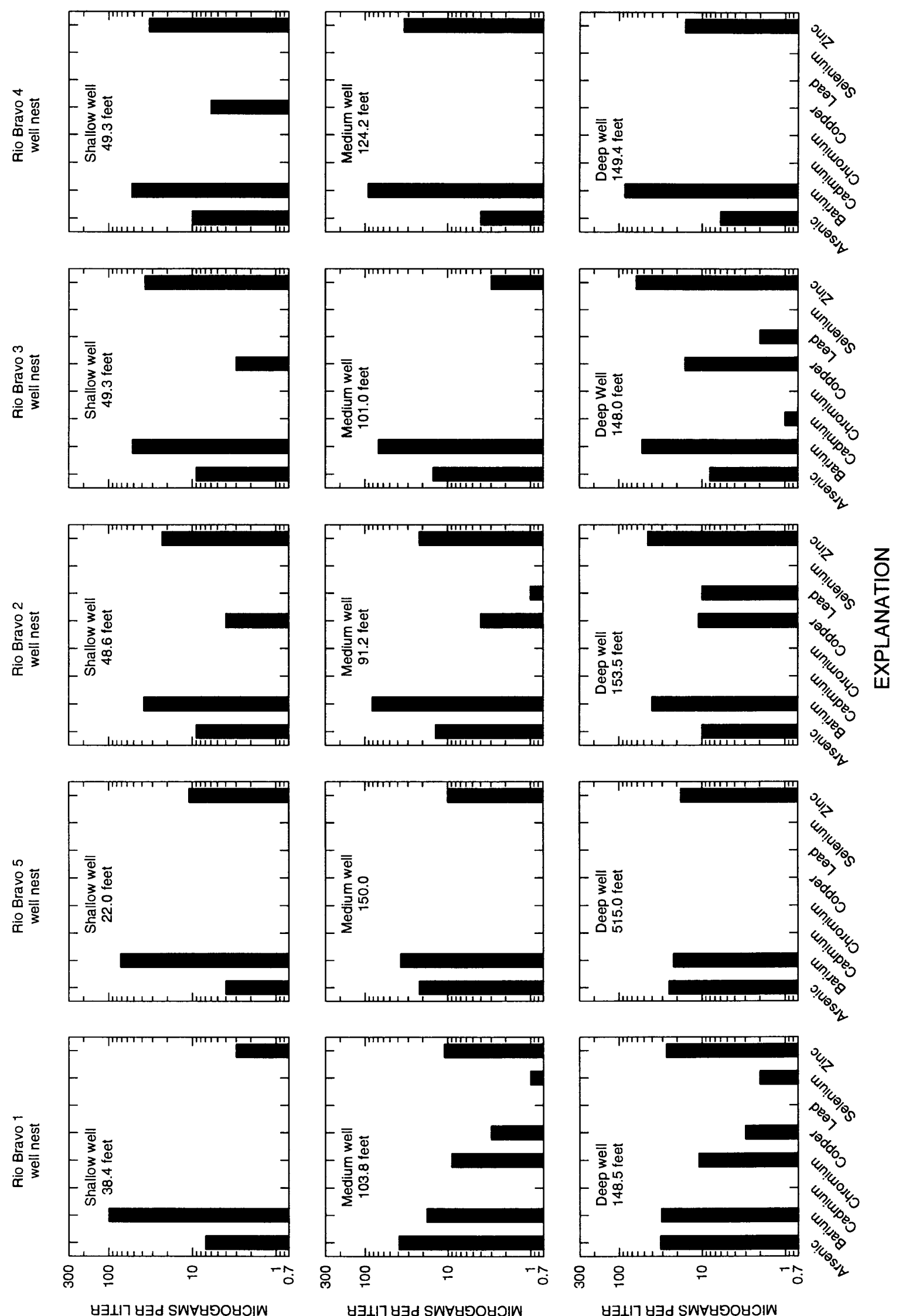

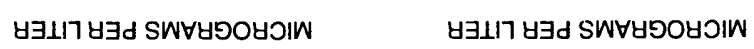




\section{SUMMARY}

Water samples from 36 observation wells in the Rio Grande Valley in the vicinity of Albuquerque, New Mexico, were collected as part of a program to investigate general groundwater-quality conditions and to determine contaminant locations in the Albuquerque area. The wells are located in three sections comprising 12 well nests. Each nest includes three wells, completed at shallow (22 to 50 feet), medium ( 75 to 150 feet), and deep (131 to 600 feet) depths. The observation wells are completed in unconsolidated alluvial deposits and Pleistocene sediments of the Santa Fe Group. The water samples were collected from October 19, 1993; through January 18, 1994.

Laboratory determinations included dissolved solids, major ions, nutrients, total organic carbon, trace elements (arsenic, barium, cadmium, chromium, copper, lead, mercury, selenium, silver, and zinc), and volatile organic compounds. Toluene was the only volatile organic compound detected; however, sample results may not be reliable since toluene was also detected in quality assurance blanks.

All water from wells in the Paseo del Norte section is a calcium bicarbonate type. Ammonia was detected in water from all wells, nitrite in no wells, nitrite plus nitrate in one well, orthophosphate in all but one well, arsenic and barium in all wells, cadmium and chromium in no wells, copper in one well, lead and selenium in no wells, and zinc in four of six wells.

All water in the Montaño section wells is a calcium bicarbonate type except in the Montaño 1 medium and deep wells, which have a calcium sulfate bicarbonate water; the Montaño 3 medium well, which has a sodium calcium bicarbonate water; and the Montaño 4 shallow well, which has a calcium sulfate water and contains the largest dissolved-solids concentration of any well of any depth, $1,280 \mathrm{mg} / \mathrm{L}$. Ammonia was detected in all water samples, nitrite in 2 wells, nitrite plus nitrate in 5 wells, orthophosphate in all but 1 well, arsenic and barium in all wells, cadmium and chromium in no wells, copper in 5 wells, lead in 1 well, selenium in no wells, and zinc in 12 of the 15 wells.

All Rio Bravo shallow wells have a calcium bicarbonate water except Rio Bravo 3, which has a sodium bicarbonate water. Rio Bravo medium wells have sodium sulfate, sodium bicarbonate, calcium sodium bicarbonate, and calcium chloride sulfate waters. Ammonia was detected in all but 2 wells, nitrite in 1 well, nitrite plus nitrate in 10 wells, orthophosphates in all but 1 well, arsenic and barium in all wells, cadmium in 1 well, chromium in 2 wells, copper in 8 wells, lead in 3 wells, selenium in 2 wells, and zinc in all wells. 


\section{SELECTED REFERENCES}

Anderholm, S.K., 1988, Ground-water chemistry of the Albuquerque-Belen Basin, central New Mexico: U.S. Geological Survey Water-Resources Investigations Report 86-4094, 110 p.

Anderholm, S.K., and Bullard, T.F., 1987, Description of piezometer nests and water levels in the Rio Grande Valley near Albuquerque, Bernalillo County, New Mexico: U.S. Geological Survey Open-File Report 87-122, $51 \mathrm{p}$.

Fishman, M.J., ed., 1993, Methods of analysis by the U.S. Geological Survey National Water Quality Laboratory--Determination of inorganic and organic constituents in water and fluvial sediments: U.S. Geological Survey Open-File Report 93-125, 217 p.

Fishman, M.J., and Friedman, L.C., eds., 1989, Methods for determination of inorganic substances in water and fluvial sediments: U.S. Geological Survey Techniques of Water-Resources Investigations, book 5 , chap. A1, $545 \mathrm{p}$.

Hines, W.G., 1981, Preliminary evaluation of nitrate pollution in shallow ground water of the Mountainview community, Bernalillo County, New Mexico: Report submitted to the New Mexico Environmental Improvement Division, $12 \mathrm{p}$.

Knapton, J.R., 1985, Field guidelines for collection, treatment, and analysis of water samples, Montana District: U.S. Geological Survey Open-File Report 85-409, 86 p.

McQuillan, D.M., 1982, Pollution of the Rio Grande valley-fill aquifer, in Guidebook to Albuquerque Country II: New Mexico Geological Society, 33d Field Conference, p. 357-360.

Thorn, C.R., McAda, D.P., and Kernodle, J.M., 1993, Geohydrologic framework and hydrologic conditions in the Albuquerque Basin, central New Mexico: U.S. Geological Survey WaterResources Investigations Report 93-4149, 106 p.

Timme, P.J., 1994, National Water Quality Laboratory 1994 services catalog: U.S. Geological Survey Open-File Report 94-304, 100 p.

U.S. Environmental Protection Agency, 1988, Methods for the determination of organic compounds in drinking water: EPA-600/4-88/039, revision 3.0, p. 285-323. 